Discussion Paper No. 16-056

\title{
The Economic Impacts of
}

\section{Telecommunications Networks and} Broadband Internet: A Survey

Irene Bertschek, Wolfgang Briglauer,

Kai Hüschelrath, Benedikt Kauf, and Thomas Niebel

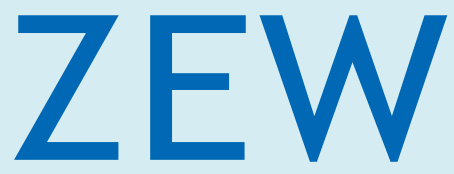

Zentrum für Europäische Wirtschaftsforschung $\mathrm{GmbH}$

Centre for European

Economic Research 
Discussion Paper No. 16-056

\title{
The Economic Impacts of Telecommunications Networks and Broadband Internet: A Survey
}

\author{
Irene Bertschek, Wolfgang Briglauer, \\ Kai Hüschelrath, Benedikt Kauf, and Thomas Niebel
}

Download this ZEW Discussion Paper from our ftp server:

http://ftp.zew.de/pub/zew-docs/dp/dp16056.pdf

Die Discussion Papers dienen einer möglichst schnellen Verbreitung von neueren Forschungsarbeiten des ZEW. Die Beiträge liegen in alleiniger Verantwortung der Autoren und stellen nicht notwendigerweise die Meinung des ZEW dar.

Discussion Papers are intended to make results of ZEW research promptly available to other economists in order to encourage discussion and suggestions for revisions. The authors are solely responsible for the contents which do not necessarily represent the opinion of the ZEW. 


\title{
THE ECONOMIC IMPACTS OF TELECOMMUNICATIONS NETWORKS AND BROADBAND INTERNET: A SURVEY
}

\author{
Irene Bertschek", Wolfgang Briglauer*, Kai Hüschelrath*, \\ Benedikt Kauf ${ }^{\dagger}$, and Thomas Niebel ${ }^{\circ}$
}

August 2016

\begin{abstract}
We provide a structured overview of the quantitative literature on the economic impacts of telecommunications networks and broadband internet. Differentiating between wireline and wireless technologies as well as broadband availability and broadband adoption, respectively, we review studies investigating the impacts on economic growth, employment and regional development as well as productivity and firm performance. Eventually, the survey does not only allow the identification of main research gaps but also provides useful information for policy makers on the significance and importance of communication networks for social welfare.
\end{abstract}

JEL Class: D24; J23; J24; L96; O33; O47

Keywords: Telecommunications; Broadband; Economic Growth; Employment; Regional Development; Productivity

ZEW Centre for European Economic Research, MaCCI Mannheim Centre for Competition and Innovation and University of Mannheim, P.O. Box 1034 43, D-68034 Mannheim, Germany, E-mail: bertschek@zew.de, Corresponding author.

* ZEW Centre for European Economic Research and MaCCI Mannheim Centre for Competition and Innovation, P.O. Box 1034 43, D-68034 Mannheim, Germany, E-mail: briglauer@zew.de.

* ZEW Centre for European Economic Research, MaCCI Mannheim Centre for Competition and Innovation and University of Mannheim, P.O. Box 1034 43, D-68034 Mannheim, Germany, E-mail: hueschelrath@zew.de.

† ZEW Centre for European Economic Research, P.O. Box 1034 43, D-68034 Mannheim, Germany, E-mail: benediktkauf@aol.com.

ZEW Centre for European Economic Research, P.O. Box 1034 43, D-68034 Mannheim, Germany, E-mail: niebel@zew.de.

We thank Benjamin Engelstätter for helpful comments and Julian Hidalgo for research assistance. Financial support by the ZEW Sponsors' Association for Science and Practice is gratefully acknowledged. 


\section{Introduction}

Among the technological advances of the last 50 years, the expansion and technological improvements of telecommunications infrastructure have been some of the most crucial. While the deployment of wireline telecommunications networks allowed large parts of the world's population, especially in developed countries, to communicate via fixed-line telephony, the introduction of first and second-generation wireless telecommunications networks since the 1980's set another landmark for personal communications. However, the progress in information and communications technologies (ICT) was not limited to voice telephony only. Broadband internet technologies such as Digital Subscriber Line (DSL) or Cable Internet have created unprecedented opportunities for worldwide data transmission. In the last years, the deployment of so-called next-generation broadband networks has facilitated much faster up- and download speeds as fiber-based wireline broadband access technologies like FTTH (Fiber-to-the-Home), Fiber-to-the-Building (FTTB) or hybrid Fiber-to-the-Cabinet (FTTC) and Fiber-to-the-Node (FTTN) technologies have started to replace the slower entirely copper- or coax-based first-generation wireline technologies. The introduction of the fourth generation (4G) mobile broadband technology Long Term Evolution (LTE) in 2010 brought substantial speed improvement for the wireless telecommunications networks.

Besides the benefits that these technologies have on the social lives of their consumers, their possible economic benefits have been increasingly emphasized by economic research. In particular, early estimations by Crandall and Jackson (2001) suggest that broadband technologies can create substantial amounts of consumer surplus. Furthermore, broadband internet is expected to generate new employment opportunities particularly in remote areas as it enables a large amount of workers to work from home (so-called telecommuting) and thus reduces the importance of distances.

Due to these advantages, broadband technologies have also gained the attention of policy makers in recent times. In 2010, the Federal Communications Commission (FCC) released the National Broadband Plan whose aims include that 'every American should have affordable access to robust broadband service' and 'at least 100 million U.S. homes should have affordable access to actual download speeds of at least 100 megabits per second and actual upload speeds of at least 50 megabits per second' until 2020 (FCC 2010a, pp. 9-10). Similarly, the European Commission launched the Digital Agenda for Europe (DAE) that 'seeks to ensure that, by 2020, (i) all Europeans will have access to much higher internet speeds of above $30 \mathrm{Mbit} / \mathrm{s}$ and (ii) 50\% or more of European households will subscribe to 
internet connections above 100 Mbit/s' (European Commission 2010, pp. 19). While achieving these goals promises considerable economic returns, they also go along with substantial costs, in particular for the construction of the necessary new communications infrastructure which is partly or entirely fiber-based. It is hence a necessity to carefully evaluate whether these returns will exceed the accompanying costs or whether the expansion of new (high-speed) broadband networks will go along with economic losses.

The central purpose of this survey is to provide a structured overview of the relevant empirical literature focusing on the impacts of telecommunications and broadband infrastructure and services on important economic indicators thereby focusing on productivity, growth, employment and regional development. In order to obtain appropriate guidelines for future public policies, we will only review quantitative research that attempts to identify causal links between telecommunications/broadband infrastructure (availability or coverage on the supply-side) or services (usage or adoption/penetration on the demand-side) and key economic variables ${ }^{1}$. Based on a thorough reading of the literature we aim to find answers to the following research questions (RQs):

- Do telecommunications and/or broadband infrastructure and services have a significant positive effect on relevant economic outcome indicators (RQ 1)?

- Do the economic impacts of wireline and wireless infrastructure and services differ from each other (RQ 2)?

- Does the availability of infrastructure produce different economic impacts than the actual usage (RQ 3)?

- Do the microeconomic studies confirm or challenge the results of the macroeconomic studies (RQ 4)?

The answers to these questions will provide an important assistance for public policy makers especially with regard to the further expansion of next-generations broadband infrastructures and services. Furthermore, it allows us to identify main research gaps in the existing literature that prevent more effective policy conclusions.

Previous surveys by Draca et al. (2007) and Cardona et al. (2013) focus on productivity as an outcome measure and consider ICT as an aggregate input measure. In this survey, we focus on telecommunication and broadband infrastructure as a specific type of ICT. Both fixed ('wireline') and mobile ('wireless') networks will be included in the evaluation of the

\footnotetext{
1 Accordingly, we exclude qualitative as well as simulation-based studies.
} 
economic impacts of telecommunications and broadband infrastructure and services. Moreover, we will specify whether broadband or telecommunications infrastructure is merely available to the public or whether the technology is actually being used. The actual consumption of services provided by a certain technology will be referred to as usage or adoption/penetration of the technology whereas the existence of infrastructure will be noted as the availability or coverage of the technology. In general, the availability of infrastructure quantifies real investment activities of telecommunications operators while the adoption of a technology quantifies the extent of consumers' willingness to pay since only those consumers or businesses whose willingness to pay is sufficient will subscribe to the offered services. Due to the often missing differentiation between broadband technologies, the broadband variables will mostly capture a mix of broadband technologies. In case a study concentrates on a specific high-speed broadband technology, we will indicate this technology accordingly. A detailed definition of the most relevant wireline and wireless technologies can be found in the Appendix.

The remainder of the article is structured as follows. Section 2 reviews the literature on the economic impacts of narrowband telecommunications networks whereas Section 3 provides a review of the empirical literature related to the economic impacts of broadband internet - with both sections featuring interim conclusions and tabular summaries. Finally, Section 4 derives overall conclusions as well as policy implications and identifies major research gaps.

\section{The economic impacts of telecommunications networks}

In this section, we focus on the economic impacts of telecommunications networks. Section 2.1 reviews studies focusing on the impact of telecommunications networks on economic growth and Section 2.2 reviews studies that examine the impacts on productivity and firm/market performance - both in ascending chronological order. Subsequently, Section 2.3 will feature interim conclusions.

\subsection{Economic growth}

Cronin et al. (1991) test the causal direction of the relationship between telecommunications investment and economic growth by using data for the U.S. from 1958 to 1988. For this purpose, Granger causality, Sims and Modified Sims tests with second-order lag structure are performed on the first differences of the variables for telecommunications investment, gross national product (GNP) and total output. The authors find significant evidence for 
bidirectional causal relationships between telecommunications investment and GNP as well as total output.

Madden and Savage (1998) analyze the relationship between telecommunications investment and economic growth in Central and Eastern Europe using data for 27 countries from 1990 to 1995. The authors estimate static cross-country growth equations at the aggregate and the sectoral level by ordinary least squares regressions (OLS). The results show that a higher share of telecommunications investment in GDP significantly increases real GDP growth per capita. For a subset of 8 countries, real telecommunications investment, as measured by the growth rate of mainlines per 100 inhabitants, is associated with a significant positive increase in GDP growth per capita in the industrial sector. Moreover, Granger-causality tests provide evidence of mutual precedence between real economic growth and telecommunications investment at the aggregate level.

Madden and Savage (2000) investigate the effects of telecommunications investment on GDP growth using data for 43 countries from 1975 to 1990. Telecommunications investment is measured by the share of telecommunications investment in GDP and the number of mainlines per working age population. The authors employ ordinary least squares and instrumental variable regressions to estimate a dynamic augmented supply-side growth model based on Mankiw et al. (1992). The results show a significant positive impact of telecommunications investment on the growth of GDP per capita for both telecommunications measures.

Dutta (2001) analyzes the causal links between telecommunications infrastructure and economic growth with data for 15 developing and 15 industrialized countries from 1960 to 1993. For this purpose, Granger causality tests are applied in which telecommunications usage is quantified through the number of telephones (total and per 100 inhabitants). Using both the original variables and their logarithmic transformations, the authors observe that telecommunications infrastructure Granger-causes economic growth in over half of the examined developing countries. Similar results are obtained for industrialized countries even though Granger-causality is found in slightly less countries. In contrast, significantly fewer countries show signs of a causal impact of economic growth on telecommunications. Based on these findings, the authors conclude that a unidirectional causal effect of telecommunications on economic growth is more probable than a bidirectional relationship between the two variables. 
Röller and Waverman (2001) use data for 21 OECD countries from 1970 to 1990 to analyze the influence of wireline telecommunications on GDP growth. In order to address potential reverse causality, the authors apply a structural model, which endogenizes telecommunication investment. Subsequently, all equations are estimated by nonlinear Generalized Method of Moments. The results show that the increase in the number of mainlines per capita positively impacts economic growth. Overall, telecommunications infrastructure is estimated to account for approximately one third of annual GDP growth between 1970 and 1990. Furthermore, the impact of telecommunications infrastructure is found to be nonlinear so that countries with a penetration rate of more than 40 percent (close to universal service given 2 to 2.5 persons per household) experience significantly higher growth than countries with low or medium penetration rates. These findings provide evidence for a critical mass phenomenon as well as network externalities and suggest that developing countries with low adoption rates would need considerable advancement to reach growth effects similar to high penetration countries.

Yilmaz et al. (2002) assess the role of spillover effects of telecommunications infrastructure investment on regional economic growth by utilizing state-level data for the U.S. from 1970 to 1997. The authors estimate a production-function model with network and geographical spillovers variables by first-differenced generalized least squares and weighted two-stage least squares regressions. The results indicate that while an increase in a state's telecommunications capital stock has a significant positive impact on its output growth, this also produces significant negative spillover effects for other states. In the years from 1984 to 1997, geographical proximity to a state increasing its telecommunications investment further adds to these negative spillover effects.

Datta and Agarwal (2004) employ a dynamic fixed-effects panel data model to examine the impact of telecommunications adoption on economic growth for 22 OECD countries from 1980 to 1992. A higher number of access lines per 100 inhabitants is found to significantly increase real GDP per capita for the examined country sample. The significant positive coefficients for lagged values of the telecommunications infrastructure variable also suggest that this impact is causal. Moreover, the authors find decreasing returns to telecommunications infrastructure which implies a stronger impact of telecommunications adoption in developing countries with few access lines.

Waverman et al. (2005) utilize data for 38 developing countries from 1996 to 2003 to investigate the influence of mobile telecommunications adoption on GDP growth. As a first approach, the authors adopt the simultaneous equations model approach of Röller and 
Waverman (2001) which is estimated by Generalized Method of Moments. While the estimations suggest a significant positive impact of mobile telecommunications, this impact appears to be overstated and is not robust to the inclusion of different countries as well as to adjustments of model specifications. Consequently, the authors estimate a cross-sectional endogenous growth model similar to Barro (1991) estimated by ordinary least squares regressions and employ data for 92 countries from 1980 and 1996 to 2003. The estimations indicate that while a higher average mobile penetration level for the years from 1996 to 2003 led to a significant increase in the average growth rate of GDP per capita from 1980 to 2003, the level of fixed-line penetration in 1980 did not have a significant effect. In particular, the effect of mobile adoption was twice as large for low income countries relative to the high income countries. Moreover, Hausman tests indicate that reverse causality did not present a problem in the examined case.

Sridhar and Sridhar (2007) study the effects of telecommunications adoption on economic growth in developing countries by using panel data for 63 developing countries from 1990 to 2001. Based on Röller and Waverman (2001), they estimate a system of equations that endogenizes economic growth and telecommunications adoption using a three-stage least square regressions methodology. When mainline and mobile phone adoption are evaluated together, an increment in the number of telephones per 100 inhabitants is associated with a significant increase in GDP which ranges between 0.1 (with country fixed effects) and 0.15 (without country fixed effects) percent for a 1 percent increase in telephone penetration. Considering only landline penetration, the same increase in telephone penetration is estimated to increase GDP by 0.14 percent in both specifications. Overall, growth in landline penetration accounted for an average GDP increase of 1.62 percent in the observed countries. Compared to mainlines, the positive impact of mobile telephones is considerably smaller with a 1 percent increase in penetration leading to an increase in GDP of less than 0.01 percent in the country fixed effects specification. The high growth rates of mobile phone penetration, contributed on average 2.48 percent to GDP in the examined countries.

Shiu and Lam (2008) analyze the links between telecommunications adoption and economic growth using a panel data for 22 Chinese provinces for the period from 1978 to 2004. The authors employ a dynamic panel data model whose first-differenced form is estimated by Arellano-Bond estimators and subsequently apply Granger causality tests. For the full sample of provinces, a unidirectional causal effect of real GDP on telecommunications usage is found. In a more detailed geographical analysis, a causal impact of telecommunications on 
real GDP is found for high-income provinces in the Eastern region, but not in the low-income central and western provinces. Similarly, telecommunications has a causal effect on economic growth in provinces with high adoption rates while provinces with low penetration rates experience no effect. These findings are in line with other studies that find returns on telecommunications to be increasing in higher adoption rates and argue in favor of a critical mass.

Lam and Shiu (2010) use panel data for 105 countries from 1980 to 2006 to evaluate the relationship between telecommunications adoption and economic growth. For this purpose, the authors estimate a dynamic panel data model in first-differenced form by Generalized Method of Moments estimators and subsequently test for Granger causality. While no causal impact of telecommunications on economic growth is found for the full country sample, this impact is observed for Europe (bidirectional) as well as Asia and Oceania when regions are examined individually. Moreover, the results also suggest a bidirectional causal relationship in countries with high incomes. For the period from 1997 to 2006, the authors further obtain a bidirectional causal relationship between mobile telecommunications and economic growth for the full country sample and every categorization of countries that is particularly strong for African countries.

Chakraborty and Nandi (2011) analyze the links between mainline access per 100 inhabitants and GDP per capita by employing unit root tests, panel cointegration and Granger causality tests on a panel data for 93 developing countries from 1985 to 2007. For the full country sample, the authors find evidence for a unidirectional causal effect of GDP per capita on telecommunications adoption in the short run and a bidirectional causal relationship between the two variables in the long run. A more detailed analysis reveals that a bidirectional causal link in both the short and the long run exists for less developed countries and countries with high growth rates. High-growth countries display a particularly strong relationship between mainline telecommunications and economic growth in the long run, whereas the more developed countries in the sample exhibit the same causality pattern as the complete sample of countries. Based on these results, the authors conclude that telecommunications infrastructure investment could be a pivotal instrument in the catch-up process of countries with lower levels of infrastructure and economic development.

Gruber and Koutroumpis (2011) employ data for 192 countries from 1990 to 2007 in order to study the relationship between mobile telecommunications adoption and economic growth. Following Röller and Waverman (2001), the authors use a simultaneous equations model with 
a macro production function and demand and supply equations for mobile infrastructure as their main approach. The obtained results are then compared to estimations from static fixedeffect ordinary least squares and instrumental variable regressions. Regardless of specification, the number of mobile lines has a significant positive impact on GDP that is largest in the instrumental variable regressions while the number of fixed lines has a contrary effect. However, the impact of mobile lines is nonlinear and increasing in a country's mobile penetration rate and income. Mobile telecommunications are estimated to cause average growth returns of annually 0.2 percent in high income countries and 0.11 percent in low income countries. In line with these findings, the authors identify a critical mass at a penetration rate of 30 percent.

Lee et al. (2012) investigate the influence of landline and mobile telecommunications adoption on the growth of GDP per capita using panel data for 44 sub-Saharan African countries from 1975 to 2006. To account for reverse causality, the authors employ two-step difference Generalized Method of Moments estimators to estimate a dynamic panel data growth model similar to Datta and Agarwal (2004). For the period from 1975 to 2006, the number of main telephone lines per 100 inhabitants is found to have a significant positive impact on growth of GDP per capita. Contrary to that, the effect of the number of mobile phone subscribers per 100 inhabitants is insignificant, which might be due to the relatively recent introduction of mobile phones. Indeed, only mobile telecommunications are associated with a significant increase in GDP growth when the analysis is confined to the years from 2000 to 2006. The negative coefficient for the interaction term between landline and mobile telecommunications in this specification further suggests that the impact of mobile phones on GDP growth is higher in countries with low levels of landlines. When landline and mobile telecommunications are combined, the authors find no significant effect of telecommunications on GDP growth.

Ward and Zheng (2016) evaluate the impact of fixed and mobile telecommunications adoption on economic growth in China by employing industry- and province-level panel data for 31 Chinese provinces from 1991 to 2010. The authors apply static two-way fixed-effect ordinary least squares regressions as well as dynamic system Generalized Method of Moments estimations in which telecommunications subscriptions are at first assumed to be exogenous and later instrumented for in order to account for possible endogeneity. The estimations indicate a significant positive effect of the number of mobile phone subscriptions on the growth rate of GDP per capita that was particularly strong for the years from 1991 to 
2000. Consistent with the theory that mobile telecommunications mainly affect less developed regions, the authors further find that the underdeveloped western region of China benefitted relatively more from mobile telecommunications than the wealthier eastern region for the period from 1991 to 2000. For the years from 2001 to 2010 however, no such difference in impact is observed. In a similar vein, complementarity between fixed and mobile telecommunications is also found only for the initial period. Contrary to the positive impact of mobile telecommunications, the number of fixed-line subscriptions negatively influenced economic growth in both regions in the latter period.

\subsection{Productivity and firm performance}

Cronin et al. (1993) employ data for the U.S. from 1958 to 1991 to investigate the influence of telecommunications investment on total factor productivity growth. In order to obtain causal effects, the authors apply Granger causality tests and modified Sims tests in which lag intervals are specified for two, four and six years. The results of these tests mostly suggest a significant and unidirectional causal impact of telecommunications investment on private business and manufacturing productivity. Further, the authors measure these effects for the period from 1963 to 1991 by using industry-level data and comparing actual productivity outcomes to hypothetical productivity outcomes which result from holding telecommunications technology constant at the level of 1963. It is found that improvements in telecommunications accounted for up to 37 percent of annual growth in total economy-wide productivity and on average for 25 percent annual productivity growth between 1975 and 1991. Moreover, almost all industries experienced a significant increase in productivity growth due to telecommunications with service sectors such as retail trade benefitting the most.

Greenstein and Spiller (1995) study the effect of telecommunications infrastructure on the finance, insurance and real estate (FIRE) sector and the manufacturing sector by employing company-, county-, state-level data for the U.S. from 1986 to 1992. Results are obtained via instrumental variable estimations of static pooled cross-section time series equations and dynamic investment adjustment models. The authors find that infrastructure deployment has a significant positive impact on real revenue in the FIRE sector. More specifically, the estimations suggest that doubling the number of miles of fiber cable would result in an increase in revenue in the FIRE sector of 10 to 45 percent depending on the specification. In contrast, no significant impact of infrastructure deployment is found for the manufacturing sector. The authors therefore argue that improved telecommunications infrastructure primarily 
benefits technology intensive industries such as the FIRE sector whereas low-tech industries like the manufacturing sector are less affected. Furthermore, the authors also caution that the effects of telecommunications on the FIRE sector might be even larger since spillover effects for other sectors and regions are not incorporated in their results.

Cieślik and Kaniewsk (2004) utilize panel data for 49 regions in Poland from 1989 to 1998 to assess the impact of telecommunications adoption on regional economic development. For this purpose, the authors use a static regional production function approach to set up a theoretical model which is empirically estimated via ordinary least squares regressions as well as fixed and random effects panel data techniques. The number of telephone subscribers per 100.000 inhabitants exerts a highly significant positive impact on retail sales per worker across all specifications even though the size of the coefficient is considerably higher in the ordinary least squares regressions. To ensure the causality of this effect, the authors also apply Hsiao's Granger tests. The results of all specifications suggest that the observed impact of telecommunications infrastructure is causal. However, this study does not examine whether the impact is bidirectional.

Jensen (2007) studies the effect of mobile phone availability on price dispersion and social welfare in fish markets in the Indian state of Kerala based on weekly survey data from 1996 to 2001. The individual markets are assorted into 3 regions according to their district affiliation. Difference-in-differences estimations are performed in which treatment is defined as the introduction of mobile phone availability in a region. Mobile phone availability is associated with a significant decrease in price dispersion across all regions and a 38 percentage point decline of the coefficient of variation for pooled treatments. This reduction in price dispersion also causes most markets to converge closely to the Law of One Price. Moreover, the availability of mobile phones significantly improves static efficiency such that the amount of wasted unsold fish is effectively reduced to zero. Further estimations suggest that while average prices for fish decreases, larger amounts of fish are sold and average daily profits are around 9 percent higher. This positive effect on profits is also partially experienced by sellers without mobile phones. The introduction of mobile phones thus provides positive external effects for non-users. Finally, the reduction in consumer retail prices has a significant positive, albeit small, effect on consumer surplus.

Thompson and Garbacz (2007) assess the influence of telecommunications adoption on productive efficiency by using panel data for 93 countries from 1995 to 2003. For this purpose, the authors employ a one-stage stochastic-frontier production function approach to 
derive inefficiency functions for different groups of countries. The estimated inefficiency functions show clear differences between regions regarding the impact of telecommunications. While productive efficiency in low income and sub-Saharan African countries can significantly benefit from increasing mobile phone and fixed-line telecommunications adoption, only increased fixed-line adoption in Latin American countries and increased mobile phone adoption in Asian countries are found to have a significantly positive impact. Furthermore, high-income OECD countries which already have nearuniversal telecommunications adoption do not experience significant positive effects from further increases in telecommunications penetration. These findings support the notion that the deployment of telecommunications infrastructure can be a helpful instrument for particularly stimulating economic development in poor and developing regions.

Muto and Yamano (2009) analyze the influence of mobile phone coverage and adoption on market participation and market outcomes of farmers in developing countries by using household- and community-level survey panel data for Uganda from 2003 and 2005. By applying static fixed-effect regressions and static fixed-effect instrumental variable regressions, the authors find that farmers that cultivate bananas and live in remote areas, are more likely to sell their crop if their community has access to a mobile phone network. In particular banana farmers with small amounts of land benefit more from mobile phone coverage than large banana farmers. The smaller farmers improve access to information more than larger farmers who already had better access to information and more social contacts before. However, these findings are only limited to the sales of bananas (perishable good) whereas no significant impact on the sales of maize (non-perishable good) is observed.

Aker (2010) utilizes trader- and market-level data for grain markets in Niger from 1999 to 2007 to evaluate the impact of mobile phone introduction on price dispersion. The author uses a difference-in-differences approach with pooled treatments in which a pair of markets has received treatment if both markets have access to the services of a mobile phone tower. To further test for robustness, propensity score matching techniques and a falsification test are employed. Across almost all specifications, the introduction of mobile phone availability significantly decreased price dispersion between markets by at least 10 percent with the majority of the reduction being realized after the first three months. With the addition of interaction terms, the impact of mobile phones is found to be the strongest between markets that face high transport costs such as distant markets and markets connected by unpaved roads. Further analysis provides evidence that the decrease in price dispersion is not caused by 
spillover effects or collusive behavior of traders but rather due to lower search costs and improved marketing strategies.

Forero (2013) uses panel data for 23 low-income and 18 high-income countries from 1980 to 2009 in order to analyze the impact of mobile telecommunications adoption on technical efficiency. The author applies a stochastic-frontier production function approach similar to Thompson and Garbacz (2007) but employs a flexible transcendental logarithmic production function instead of a Cobb-Douglas production function and includes fixed effects. The estimation results show that higher numbers of subscribers to mobile phone services per 100 inhabitants significantly contribute to decreases in technical inefficiency with the effect being particularly strong in Asian and Latin American countries. The inclusion of lagged values of mobile phone usage further provides evidence that the impact of mobile telecommunications on technical efficiency is causal in low-income countries whereas no causality is found for high-income countries.

\subsection{Conclusions on the economic impacts of telecommunications networks}

The main results of the reviewed papers studying the economic impacts of telecommunications networks are presented in ascending chronological order in Table 1 ('impact on economic growth') and Table 2 ('impacts on productivity and firm/market performance). In both tables, we apply a further separation into studies examining wireline and wireless telecommunications networks.

Overall, a majority of 13 studies reviewed provide evidence that economic growth measured by GDP/GNP or GDP per capita is significantly and positively affected by landline telecommunications with all of the 10 studies with data at the country level finding such an effect for at least some of the examined countries. However, some studies also indicate that the positive effect of telecommunications is mostly present in developed countries with a high number of mainlines whereas evidence for developing countries with a lower number of mainlines is slightly less conclusive. In contrast to wireline telecommunications, mobile telecommunications networks are found to significantly enhance economic growth in developed but even more so in less developed countries. Lee et al. (2012) further demonstrate that the impact of mobile telecommunications is stronger in developing countries with less developed wireline telecommunications infrastructure. Based on these findings, developing countries should put their focus on the further deployment of mobile telecommunications if they want to stimulate economic growth effectively. 
All of the studies focusing on both wireline and wireless telecommunications find at least partially significant positive impacts on productivity, firm performance or market performance. On the sectoral level, Cronin et al. (1993) and Greenstein and Spiller (1995) provide evidence that the benefits of wireline telecommunications are particularly concentrated in service sectors which generally require higher skilled workers. In contrast, studies by Jensen (2007) and Aker (2010) suggest that mobile telecommunications can help agricultural markets in developing countries to be more efficient and increase social welfare.

In sum, the reviewed studies provide strong evidence that telecommunications networks (fixed-line and mobile) exert positive effects on economic growth as well as national and sectoral productivity (RQ 1). Regarding research question 2 (RQ 2), we find that mobile telecommunications networks have a stronger positive impact on developing countries while wireline telecommunications networks rather benefit developed countries. Furthermore, we observe no distinguished difference between the availability (infrastructure investment) and the adoption of both wireline and wireless telecommunications networks (RQ 3). Almost all microeconomic studies regarding the effects of wireline and wireless telecommunication networks on growth and productivity find positive effects in line with the macroeconomic country-level studies (RQ 4). 
Table 1: Telecommunications' impact on economic growth

\begin{tabular}{|c|c|c|c|}
\hline Authors & Data & Methodology & Main results \\
\hline \multicolumn{4}{|c|}{ Wireline telecommunications } \\
\hline $\begin{array}{l}\text { Cronin } \\
\text { et al. } \\
\text { (1991) }\end{array}$ & $\begin{array}{l}\text { USA; 1958- } \\
\text { 1988; } \\
\text { country-level }\end{array}$ & $\begin{array}{l}\text { Granger, Sims and modified } \\
\text { Sims tests performed on first- } \\
\text { differenced variables }\end{array}$ & 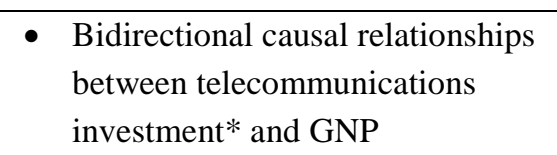 \\
\hline $\begin{array}{l}\text { Madden \& } \\
\text { Savage } \\
(1998)\end{array}$ & $\begin{array}{l}27 \text { Central and } \\
\text { Eastern } \\
\text { European } \\
\text { countries; } \\
\text { 1990-1995; } \\
\text { country-level }\end{array}$ & $\begin{array}{l}\text { Static growth equations } \\
\text { estimated by ordinary least } \\
\text { squares regressions; Hsiao’s } \\
\text { Granger causality tests to } \\
\text { determine the timing of effects }\end{array}$ & $\begin{array}{l}\text { Monetary/real wireline } \\
\text { telecommunications investment } \\
\text { has a positive impact on growth of } \\
\text { GDP per capita for the whole } \\
\text { economy/the industrial sector } \\
\text { - Real investment precedes } \\
\text { (Granger causes) GDP growth } \\
\text { while monetary investment does } \\
\text { not }\end{array}$ \\
\hline $\begin{array}{l}\text { Madden \& } \\
\text { Savage } \\
(2000)\end{array}$ & $\begin{array}{l}43 \text { countries; } \\
\text { 1975-1990; } \\
\text { country-level }\end{array}$ & $\begin{array}{l}\text { Dynamic augmented growth } \\
\text { model estimated by ordinary } \\
\text { least squares and instrumental } \\
\text { variable regressions }\end{array}$ & $\begin{array}{l}\text { - Both monetary and real wireline } \\
\text { telecommunications investment } \\
\text { positively affect growth of GDP } \\
\text { per capita }\end{array}$ \\
\hline $\begin{array}{l}\text { Dutta } \\
(2001)\end{array}$ & $\begin{array}{l}15 \text { industrial. } \\
\text { and } 15 \\
\text { develop. } \\
\text { countries; } \\
\text { 1960-1993; } \\
\text { country-level }\end{array}$ & $\begin{array}{l}\text { Granger causality tests for all } \\
\text { countries individually }\end{array}$ & $\begin{array}{l}\text { - A causal effect of } \\
\text { telecommunications usage* on } \\
\text { economic growth is found for } \\
\text { more countries than a causal effect } \\
\text { in the other direction }\end{array}$ \\
\hline $\begin{array}{l}\text { Röller \& } \\
\text { Waverman } \\
\text { (2001) }\end{array}$ & $\begin{array}{l}21 \text { OECD } \\
\text { countries; } \\
\text { 1970-1990; } \\
\text { country-level }\end{array}$ & $\begin{array}{l}\text { Simultaneous equations model } \\
\text { with a macro production } \\
\text { function and demand and supply } \\
\text { equations for } \\
\text { telecommunications investment } \\
\text { estimated by nonlinear } \\
\text { Generalized Method of } \\
\text { Moments }\end{array}$ & $\begin{array}{l}\text { Wireline telecommunications } \\
\text { adoption positively affects GDP } \\
\text { growth } \\
\text { - Evidence for a critical mass of } \\
\text { telecommunications infrastructure } \\
\text { at an adoption rate of } 40 \text { percent }\end{array}$ \\
\hline
\end{tabular}


(Table 1: Continued)

\begin{tabular}{|c|c|c|c|}
\hline Authors & Data & Methodology & Main results \\
\hline \multicolumn{4}{|c|}{ Wireline telecommunications } \\
\hline $\begin{array}{l}\text { Yilmaz } \\
\text { et al. } \\
(2002)\end{array}$ & $\begin{array}{l}\text { USA; } \\
\text { 1970-1997; } \\
\text { state-level }\end{array}$ & $\begin{array}{l}\text { Static classical production } \\
\text { function approach estimated by } \\
\text { first-differenced generalized and } \\
\text { weighted two-stage least squares } \\
\text { regressions }\end{array}$ & $\begin{array}{l}\text { - Telecommunications } \\
\text { infrastructure investment* has a } \\
\text { positive effect on output growth } \\
\text { - But: a state’s telecommunications } \\
\text { investment negatively impacts } \\
\text { output growth in the other states }\end{array}$ \\
\hline $\begin{array}{l}\text { Datta \& } \\
\text { Agarwal } \\
(2004)\end{array}$ & $\begin{array}{l}22 \text { OECD } \\
\text { countries; } \\
\text { 1980-1992; } \\
\text { country-level }\end{array}$ & $\begin{array}{l}\text { Dynamic fixed-effect panel data } \\
\text { growth model }\end{array}$ & $\begin{array}{l}\text { Wireline telecommunications } \\
\text { adoption positively affects GDP } \\
\text { per capita } \\
\text { - Decreasing returns imply larger } \\
\text { effects in developing countries }\end{array}$ \\
\hline $\begin{array}{l}\text { Sridhar \& } \\
\text { Sridhar } \\
\text { (2007) }\end{array}$ & $\begin{array}{l}63 \text { countries; } \\
1990-2001 ; \\
\text { country-level }\end{array}$ & $\begin{array}{l}\text { Simultaneous equations model } \\
\text { estimated by three-stage least } \\
\text { squares regressions }\end{array}$ & $\begin{array}{l}\text { - Wireline telephone adoption has a } \\
\text { significant positive impact on } \\
\text { GDP growth }\end{array}$ \\
\hline $\begin{array}{l}\text { Shiu \& } \\
\text { Lam } \\
(2008)\end{array}$ & $\begin{array}{l}22 \text { Chinese } \\
\text { provinces; } \\
\text { 1978-2004; } \\
\text { province-level }\end{array}$ & $\begin{array}{l}\text { Dynamic panel data model } \\
\text { estimated in first-differenced } \\
\text { form by Arellano-Bond } \\
\text { estimators; Granger causality } \\
\text { tests }\end{array}$ & $\begin{array}{l}\text { Wireline telecommunications } \\
\text { adoption causally impacts GDP } \\
\text { only in provinces with high } \\
\text { income/adoption rates }\end{array}$ \\
\hline $\begin{array}{l}\text { Lam \& } \\
\text { Shiu } \\
(2010)\end{array}$ & $\begin{array}{l}105 \text { countries; } \\
\text { 1980-2006; } \\
\text { country-level }\end{array}$ & $\begin{array}{l}\text { Dynamic panel data model in } \\
\text { first-differenced form estimated } \\
\text { by Generalized Method of } \\
\text { Moments, Granger causality test }\end{array}$ & $\begin{array}{l}\text { - Bidirectional causal links between } \\
\text { telecommunications adoption* } \\
\text { and economic growth in European } \\
\text { and high income countries } \\
\text { - Causal impact of GDP on } \\
\text { telecommunications adoption in } \\
\text { lower income countries }\end{array}$ \\
\hline
\end{tabular}


(Table 1: Continued)

\begin{tabular}{|c|c|c|c|}
\hline Authors & Data & Methodology & Main results \\
\hline \multicolumn{4}{|c|}{ Wireline telecommunications } \\
\hline $\begin{array}{l}\text { Chakraborty } \\
\text { \& Nandi } \\
\text { (2011) }\end{array}$ & $\begin{array}{l}\text { 93 developing } \\
\text { countries; } \\
\text { 1985-2007; } \\
\text { country-level }\end{array}$ & $\begin{array}{l}\text { Unit root tests, panel } \\
\text { cointegration and Granger } \\
\text { causality tests }\end{array}$ & 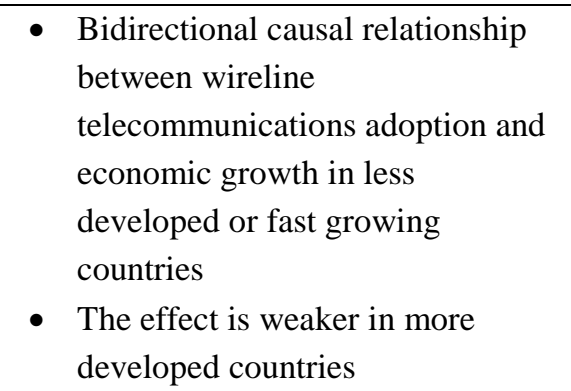 \\
\hline $\begin{array}{l}\text { Lee } \\
\text { et al. } \\
(2012)\end{array}$ & $\begin{array}{l}44 \text { sub-Saharan } \\
\text { countries; } \\
\text { 1975-2006; } \\
\text { country-level }\end{array}$ & $\begin{array}{l}\text { Dynamic panel data growth } \\
\text { model estimated by two step } \\
\text { difference Generalized Method } \\
\text { of Moments }\end{array}$ & $\begin{array}{l}\text { - Significant positive impact of } \\
\text { wireline telecommunications } \\
\text { adoption on GDP per capita }\end{array}$ \\
\hline $\begin{array}{l}\text { Ward \& } \\
\text { Zheng } \\
\text { (2016) }\end{array}$ & $\begin{array}{l}31 \text { Chinese } \\
\text { provinces; } \\
\text { 1991-2010; } \\
\text { industry- and } \\
\text { province-level }\end{array}$ & $\begin{array}{l}\text { Static two-way fixed-effect } \\
\text { ordinary least squares and } \\
\text { dynamic system Generalized } \\
\text { Method of Moments regressions } \\
\text { (with and without instruments for } \\
\text { possible endogeneity of the } \\
\text { telecommunications variable) }\end{array}$ & $\begin{array}{l}\text { - Between } 1991 \text { and 2000, fixed-line } \\
\text { subscriptions had a positive impact } \\
\text { on growth of GDP per capita in the } \\
\text { well-developed eastern provinces } \\
\text { - In contrast, fixed-line subscriptions } \\
\text { had a negative effect from } 2001 \text { to } \\
2010\end{array}$ \\
\hline
\end{tabular}


(Table 1: Continued)

\begin{tabular}{|c|c|c|c|}
\hline Authors & Data & Methodology & Main results \\
\hline \multicolumn{4}{|c|}{ Wireless telecommunications } \\
\hline $\begin{array}{l}\text { Waverman } \\
\text { et al. } \\
\text { (2005) }\end{array}$ & $\begin{array}{l}38 \text { developing } \\
\text { countries/ } 92 \\
\text { countries; } \\
\text { 1996- } \\
\text { 2003/1980- } \\
\text { 2003; } \\
\text { country-level }\end{array}$ & $\begin{array}{l}\text { Simultaneous equations model } \\
\text { estimated by Generalized } \\
\text { Method of Moments; cross- } \\
\text { sectional endogenous growth } \\
\text { model estimated by ordinary } \\
\text { least squares regressions }\end{array}$ & $\begin{array}{l}\text { - First approach: positive results are } \\
\text { not robust } \\
\text { - Second approach: mobile } \\
\text { telecommunications adoption has } \\
\text { a significant positive effect on } \\
\text { growth of GDP per capita that is } \\
\text { twice as strong in low income } \\
\text { countries }\end{array}$ \\
\hline $\begin{array}{l}\text { Sridhar \& } \\
\text { Sridhar } \\
(2007)\end{array}$ & $\begin{array}{l}63 \text { developing } \\
\text { countries; } \\
\text { 1990-2001; }\end{array}$ & $\begin{array}{l}\text { Simultaneous equations model } \\
\text { estimated by three-stage least } \\
\text { squares regressions }\end{array}$ & $\begin{array}{l}\text { - Mobile phone adoption has a } \\
\text { significant positive impact on } \\
\text { GDP growth }\end{array}$ \\
\hline
\end{tabular}

$\begin{array}{lll}\text { Lam \& } & 105 \text { countries; } & \begin{array}{l}\text { Dynamic panel data model in } \\ \text { fhiu }\end{array} \\ \begin{array}{lll}\text { (2010) } & \text { country-level } & \text { by Generalized Method of } \\ & & \text { Moments, Granger causality test }\end{array}\end{array}$

Gruber \& Koutroumpis (2011) 192 countries;

Simultaneous equations model estimated by three-stage least squares; static fixed-effect ordinary least squares and instrumental variable regressions

Lee

et al.

(2012)

44 sub-Saharan

countries;

1975-2006; country-level

Dynamic panel data growth model estimated by two step difference Generalized Method of Moments

$\begin{array}{ll}\text { Ward \& } & \text { 31 Chinese } \\ \text { Zheng } & \text { provinces; } \\ \text { (2016) } & \text { 1991-2010; } \\ & \text { industry and } \\ & \text { province-level }\end{array}$

Static two-way fixed-effect ordinary least squares and dynamic system Generalized Method of Moments regressions (with and without instruments for possible endogeneity of the telecommunications variable)
- Bidirectional causal links between mobile telecommunications adoption and economic growth for the complete country sample and high/low income countries

- Significant positive impact of mobile telecommunications infrastructure on economic growth

- Critical mass at a penetration rate of around 30 percent

- Between 2000 and 2006, significant positive effect of mobile phone adoption on GDP that is negatively correlated with wireline infrastructure

- Significant positive impact of mobile phone subscribers on growth of GDP per capita

- Between 1991 and 2000, the impact was significantly stronger in less developed provinces

\footnotetext{
* These studies either include a telecommunications variable that combines wireless and wireline technologies or do not specify which form of telecommunications is utilized. However, we assign these studies to wireline telecommunications as either their data sets often end before 2000 when wireline telecommunications networks were still the dominant technology or their data on mobile telecommunications is incomplete.
} 
Table 2: Telecommunications' impacts on productivity and firm/market performance

\begin{tabular}{|c|c|c|c|}
\hline Authors & Data & Methodology & Main results \\
\hline \multicolumn{4}{|c|}{ Wireline telecommunications } \\
\hline $\begin{array}{l}\text { Cronin } \\
\text { et al. } \\
\text { (1993) }\end{array}$ & $\begin{array}{l}\text { USA; 1958- } \\
\text { 1991; } \\
\text { industry- and } \\
\text { country-level }\end{array}$ & $\begin{array}{l}\text { Granger, Sims and modified } \\
\text { Sims tests; Peterson Indices } \\
\text { estimated by interindustry } \\
\text { economics and translog } \\
\text { production functions }\end{array}$ & 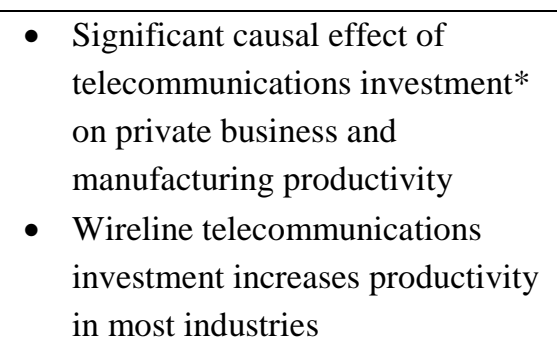 \\
\hline $\begin{array}{l}\text { Greenstein \& } \\
\text { Spiller } \\
(1995)\end{array}$ & $\begin{array}{l}\text { USA; } \\
\text { 1986-1992; } \\
\text { company-, } \\
\text { county- and } \\
\text { state-level }\end{array}$ & $\begin{array}{l}\text { Estimation of static pooled } \\
\text { cross-section time series } \\
\text { equations and dynamic } \\
\text { investment adjustment models }\end{array}$ & $\begin{array}{l}\text { - Deployment of } \\
\text { telecommunications } \\
\text { infrastructure* has a significant } \\
\text { positive effect on total revenue in } \\
\text { the technology-intensive finance, } \\
\text { insurance and real estate sectors } \\
\text { (FIRE) but no effect on the } \\
\text { manufacturing sector }\end{array}$ \\
\hline $\begin{array}{l}\text { Cieślik \& } \\
\text { Kaniewsk } \\
(2004)\end{array}$ & $\begin{array}{l}\text { Poland; } \\
\text { 1989-1998; } \\
\text { region-level }\end{array}$ & $\begin{array}{l}\text { Regional production function } \\
\text { approach estimated by ordinary } \\
\text { least squares as well as fixed- } \\
\text { effect and random effect panel } \\
\text { data regressions; Hsiao’s } \\
\text { Granger tests }\end{array}$ & $\begin{array}{l}\text { - Telecommunications adoption* } \\
\text { has a significant positive and } \\
\text { likely causal impact on retail sales } \\
\text { per worker }\end{array}$ \\
\hline $\begin{array}{l}\text { Thompson \& } \\
\text { Garbacz } \\
\text { (2007) }\end{array}$ & $\begin{array}{l}93 \text { countries; } \\
\text { 1995-2003; } \\
\text { country-level }\end{array}$ & $\begin{array}{l}\text { One-stage stochastic-frontier } \\
\text { production function approach } \\
\text { estimated by random effects } \\
\text { regressions }\end{array}$ & $\begin{array}{l}\text { - Wireline telecommunications } \\
\text { adoption significantly reduces } \\
\text { productive inefficiencies only in } \\
\text { low-income countries but has no } \\
\text { significant effect in high income } \\
\text { countries }\end{array}$ \\
\hline
\end{tabular}


(Table 2: Continued)

\begin{tabular}{lll}
\hline Authors & Data & Methodology \\
& & \\
\hline Jensen & Fish markets in & Difference-in-differences \\
the Indian state & estimations with the introduction \\
& of Kerala; & of mobile phone availability as \\
& 1996-2001 & treatment \\
& individual- & \\
& level (survey) & \\
&
\end{tabular}

Main results

$\begin{array}{lll} & & \\ \text { Thompson \& } & 93 \text { countries; } & \text { One-stage stochastic-frontier } \\ \text { Garbacz } & \text { 1995-2003; } & \text { production function approach } \\ (2007) & \text { country-level } & \end{array}$

- Mobile phone availability significantly reduces price dispersion and waste of unsold fish

- Mobile phone availability increases sellers' profits and consumer surplus

- Wireless telecommunications adoption significantly reduces productive inefficiencies only in low-income countries

$\begin{array}{lll}\text { Muto \& } & \text { Uganda, } & \text { Static fixed-effect regressions } \\ \text { Yamano } & \text { 2003-2005, } & \text { and static fixed-effect } \\ \text { (2009) } & \begin{array}{l}\text { community- } \\ \text { and household- }\end{array} & \\ & \text { instrumental variable regressions } \\ & \text { level } & \end{array}$

- Rural communities' mobile phone coverage increases the probability to sell and the quantity sold of its farmers with regard to bananas but not with regard to maize

$\begin{array}{lll}\text { Aker } & \text { 33 grain } & \text { Difference-in-differences } \\ \text { (2010) } & \text { markets in } & \begin{array}{l}\text { estimations with the introduction } \\ \text { of mobile phone towers as } \\ \text { Niger; }\end{array} \\ \begin{array}{ll}\text { 1999-2007; } \\ \text { trader- and }\end{array} & \begin{array}{l}\text { effects and lagged dependent } \\ \text { market-level }\end{array} & \text { variables }\end{array}$

Forero 23 low income Estimation of a fixed-effect

(2013) and 18 high stochastic-frontier production income function approach with a countries; translog production function

- The introduction of mobile phone towers is associated with a significant decrease in price dispersion between markets

- The effect is particularly in distant and difficult to access markets

- Mobile telecommunications adoption significantly reduces technical inefficiencies, especially in Asian and Latin American countries

1980-2009; country-level

- The effect is likely causal in lowincome countries but not in highincome countries

\footnotetext{
* These studies either include a telecommunications variable that combines wireless and wireline technologies or do not specify which form of telecommunications is utilized. However, we assign these studies to wireline telecommunications as either their data sets often end before 2000 when wireline telecommunications networks were still the dominant technology or their data on mobile telecommunications is incomplete.
} 


\section{The economic impacts of broadband internet}

In this section, we focus on the economic impacts of broadband internet. Section 3.1 investigates the effects of broadband on economic growth. Since broadband has been considered as a main driver of rural development, Section 3.2 focuses on the regional development, household outcomes and employment effects. Section 3.3 then analyzes the influence of broadband on labor and firm productivity as well as on firm performance. In all three sections, we again review the respective literature in ascending chronological order. Eventually, Section 3.4 provides interim conclusions.

\subsection{Economic growth}

Koutroumpis (2009) examines the relationship between broadband adoption and GDP growth utilizing data for 22 OECD countries from 2002 to 2007. Using a simultaneous equations model based on Röller and Waverman (2001), estimates are obtained by employing single instrumental variable and three-stage least squares Generalized Method of Moments estimators, both including country fixed effects. The author finds a significant positive impact of broadband penetration on GDP with a one percent increase in broadband adoption generating a 0.023 percent increase in GDP growth according to the fixed-effects instrumental variable specification. The estimations further imply that improvements in broadband infrastructure were responsible for nearly 10 percent of the annual growth rates of the OECD countries in the observed period. In addition, the author identifies a critical mass at a broadband adoption rate of 30 percent after which the growth returns to broadband infrastructure investments are considerably larger than before.

Czernich et al. (2011) measure broadband adoption as the number of broadband subscribers per 100 inhabitants and investigate its influence on economic growth with panel data for 25 OECD countries from 1996 to 2007. The authors apply a two-stage instrumental variable approach in which the rate of broadband adoption is estimated in the first stage through nonlinear least squares based on a logistic diffusion model. Subsequently the estimated broadband penetration rates are employed as broadband variables in two second-stage models: in the first model, broadband introduction is used as a dummy variable in difference-in-differences estimations with fixed effects; in the second model, the broadband adoption rate is used as a continuous variable in a static cross-country growth model with fixed effects. The authors find that broadband introduction increases per capita growth significantly such that the GDP per capita after the introduction of broadband was 2.7 to 3.9 percent higher than before. A 10 
percentage point increase in the broadband adoption rate increases the annual per capita growth by 0.9 to 1.5 percentage points. The authors also find evidence for a critical mass phenomenon at a broadband adoption rate of 10 percent.

Thompson and Garbacz (2011) evaluate the impact of mobile and fixed broadband adoption on economic growth utilizing panel data for 43 countries from 2005 to 2009. Fixed-effect instrumental variable regressions are applied in which static equations are estimated for high and low income countries individually and combined. In all specifications, the authors find that mobile broadband has a significant positive impact on GDP per household. However, the magnitude of this impact is larger in low income countries. In contrast, the coefficient for fixed broadband is negative but marginally significant in low income countries only.

Arvin and Pradhan (2014) establish a causal relationship between broadband adoption and economic growth employing panel data from 1998 to 2011 for 19 of the former G20 countries which are subsequently divided into developed and developing ('emerging') countries. Based on static and dynamic regressions that include variables for GDP, the number of broadband users, the degree of urbanization and the real inflow of foreign direct investment, the authors apply panel cointegration and Granger causality tests to verify causal relationships. Initially, cointegration is found between all four variables suggesting long-run causal relationships between these variables. In contrast to that, the Granger causality tests do not provide evidence for any kind of long-run causal relationship between GDP and broadband penetration. In the short run, the authors find that a bidirectional causal relationship between economic growth and broadband penetration exists only for developed countries; in developing countries, only economic growth causally impacts broadband penetration.

Gruber et al. (2014) use data for 27 European Union (EU) countries from 2005 to 2011 to evaluate the benefits and costs of the Digital Agenda for Europe (DAE). To estimate the return parameters of broadband infrastructure, the authors set up a simultaneous equations model, similar to Röller and Waverman (2001), and apply fixed-effect three-stage least squares regressions. The estimates suggest that broadband adoption rates had a significant positive effect on GDP in the observed period. Moreover, the results indicate that this effect is significantly larger for a broadband adoption rate greater than 15 percent.

\subsection{Employment and regional development}

Kandilov and Renkow (2010) use ZIP code- and county-level data for the U.S. from 1994 to 2007 for ZIP codes with a population of 20.000 inhabitants or less to examine the economic 
impacts of two programs of the U.S. Department of Agriculture on rural areas, including the Pilot Broadband Loan Program as well as the subsequent Broadband Loan Program. Employment, annual payroll and the number of business establishments are used as dependent variables in the baseline regression and estimations are obtained on the ZIP code and county level. In order to estimate the baseline regression, the authors apply a difference-indifferences fixed effects approach, including year dummies, and difference-in-differences propensity score matching estimators for nearest neighbor matching as well as other robustness checks. The authors find that only the initial Pilot Broadband Loan Program had a significant positive effect on employment, annual payroll and the number of business establishments on the zip code level whereas the subsequent Broadband Loan Program had mostly no significant impact. Overall, it cannot be concluded that the Broadband Loan Program helped to promote economic development in rural areas.

Forman et al. (2012) use U.S. county-level data to examine the relationship between Internet investment and wage growth from 1995 to 2000. The authors employ various instrumental variables to identify causal effects and find that business investment in advanced Internet technologies (such as ERP or e-commerce) comes along with significant wage and employment growth. However, this holds only for six percent of counties that were characterized by intensive IT usage, high income, high skills and high population density already before 1995. In turn, broadband internet and wage growth appear unrelated in the other counties. Thus, although the Internet lowers the cost of engaging in economic activity in geographically isolated regions, better performing regions benefit significantly more from investment in advanced Internet technologies and applications.

Kolko (2012) uses ZIP code- and county-level data for the U.S. from 1992 to 2006 to analyze the impact of the number of broadband providers on local economic outcomes. The author applies static ordinary and weighted two-stage least squares regressions in which the number of broadband providers is instrumented by the average slope of terrain within an area. Employment growth is found to be significantly and positively affected by the number of broadband providers in both specifications and also when population growth is being controlled for. Technology-intensive sectors such as scientific and technical services appear to benefit the most whereas other sectors such as mining and public administration seem not to be significantly impacted. Moreover, the significantly negative coefficient of population density implies that the impact is larger in less densely populated areas. Aside from an increase in population growth, the effects of a higher number of broadband providers on other 
household outcomes on the county level are more ambiguous: for the period from 1992 to 1999, broadband expansion positively influences employment rate, average pay per employee and median income. In contrast, no significant effect on the first two indicators and even a negative impact on median income is obtained for the period from 1999 to 2006. These results in combination with the increase in population growth suggest that the growth in employment due to higher broadband availability may initiate an influx of workers which causes workers' per capita outcomes to be un- or negatively affected. Employing household survey data, it is further shown that a higher number of broadband providers did not lead to an increase in telecommuting or home-based businesses.

Atasoy (2013) studies the labor market effects of broadband availability in U.S. counties with county-level panel data from 1999 to 2007. Using the share of population living in ZIP codes with at least one broadband provider as a measure of broadband availability, the author estimates static ordinary least squares and fixed-effect models. In addition, regressions similar to Granger causality tests as well as a falsification test are employed to check for causality. Broadband is found to have a significant and causal positive effect on the employment rate that is robust to different time trends and mainly stems from an expansion of workforce in existing firms rather than from the foundation of new businesses. The inclusion of an interaction term between broadband and education levels further shows that broadband increases employment and wages solely for workers with a college degree. In contrast, the impact of broadband on the employment rates and wages of workers without a college degree is significantly negative in this specification. In line with these results, the author also finds that the positive impact of broadband availability is more pronounced in counties with a higher number of skilled workers and in industries that require highly skilled and educated workers. On a regional level, rural areas benefit more than urban areas from increased broadband availability although the magnitude of this advantage is rather small.

Mack and Faggian (2013) use county-level data for the U.S. to assess the role of broadband availability in 1999 on changes in productivity between 2000 and 2007. To account for spatial variations between counties, the authors employ fixed-effect spatial lag models. Further, productivity is measured by earnings and interaction terms between broadband availability and workers' skill/education levels are constructed. Specifying broadband availability as a dummy variable, it is initially found that broadband availability increases productivity significantly. When interaction terms for education and skill are added, the coefficients for these terms are positive and significant while the effect of broadband availability alone 
becomes negative and significant. Similar results are obtained when the number of broadband providers is used as a continuous variable. In this case however, the coefficient for broadband availability is also significantly negative when interaction terms are excluded. These findings suggest that broadband can only develop its potential benefits if workers are sufficiently trained regarding its use and public policies should be designed accordingly.

Czernich (2014) examines the impact of DSL-based broadband availability on unemployment rates by using municipality- and county-level data for Germany from 2002 and 2006. The author initially applies a dynamic ordinary least squares regression model in which the unemployment rate in 2006 is regressed on the percentage of households with DSL availability in 2006, the unemployment rate in 2002 and various control variables. In these specifications, broadband availability has a significant negative effect on the unemployment rate even though the coefficient of the DSL rate becomes smaller and less significant when more control variables are taken into account. Similar findings are obtained when the unemployment rate of under 25 year-olds is considered instead of the overall unemployment rate although the coefficient of the DSL rate variable remains highly significant for all specifications. When the distance of a municipality to the next main distribution frame is employed as an instrument for the DSL availability rate, these results no longer hold. Instead, the dynamic instrumental variable regressions suggest that DSL availability increases unemployment albeit this effect is not statistically significant. Likewise, no significant influence is observed for the unemployment rate of under 25 year-olds. Based on these results, the author concludes that higher broadband availability does not causally imply a lower unemployment rate. However, it is also cautioned that the instrumental variable regressions only include municipalities without an own main distribution frame. Since these municipalities are mostly located in rural areas, the insignificance of the impact may be limited to rural municipalities.

Mack and Rey (2014) investigate the relationship between broadband availability and the presence of knowledge intensive businesses in 2004 by utilizing ZIP code-level data for 54 U.S. metropolitan areas. Estimating an individual model for each metropolitan area, the authors employ static ordinary or two-stage least squares regressions for areas without spatial dependence as well as spatial lag or spatial error models for areas with spatial dependence. The regression results show that broadband availability had a significantly positive impact on the number of knowledge intensive firms in 49 of the 54 metropolitan areas which suggests a generally beneficial effect of broadband. Given the industrial and geographical variety of the 
affected areas, the authors argue that broadband may not only further foster areas with already existing knowledge firm concentration but may also help areas which have no such agglomerations or suffer from large distances and high commuting costs.

Whitacre et al. (2014) employ county-level data for the U.S. from 2001 to 2010 in order to obtain a causal link between fixed residential broadband availability/adoption and rural economic development. For this purpose, the authors group non-metropolitan counties according to their performance regarding several broadband speed thresholds and subsequently perform nearest neighbor and kernel propensity score matching with logit propensity scores that are based on county characteristics in 2001. Several significant effects are observed: Firstly, counties with higher levels of broadband adoption experience faster growth in median household income and reduced growth in unemployment while counties with lower levels of broadband adoption suffer from lower growth of employment and number of firms. Moreover, high download speed is associated with lower levels of poverty and more creative class workers. On the downside, counties with higher levels of broadband availability experience lower growth in non-farm proprietor income whereas a higher growth in median household income is, to a marginal extent, prevalent in counties with low levels of broadband availability and download speed. These results suggest that both the increase of broadband adoption and the increase in available broadband speed should be emphasized by broadband policies.

Canzian et al. (2015) investigate the effects of a government initiative for ADSL2+ broadband deployment on rural communities in the Italian Province of Trento with panel data for firms (outside the agricultural and public service sector) and municipalities for the years from 2008 to 2012. Treating the deployment as a quasi-experimental set-up, the authors apply a fixedeffect difference-in-differences approach in which the provision of ADSL2+ broadband is used as a dummy variable. As an alternative measure, the number of days that ADSL2+ broadband had been available in a municipality is employed as a continuous variable. In the binary specification, the authors find that the availability of broadband had a significant positive influence on annual sales turnover and annual value added with broadband availability increasing the annual turnover by around 40 percent and the annual value added by around 25 percent over the years from 2010 to 2012. Similar results are obtained for the continuous variable specification even though the treatment effect for the annual sales turnover is nonlinear. Placebo analysis for the years from 2008 to 2010 suggests that the effects are causal. On the sectoral level, the authors find that the majority of observed sectors 
significantly benefit from broadband availability and that these benefits are particularly large for hotels and restaurants as well as professional, scientific, technical and administrative services. However, no specific increase in impact is observed for the high-tech sector.

Ahlfeldt et al. (forthcoming) employ transaction- and local exchange-level data for England from 1995 to 2010 and individual speed test data from 2009 and 2010 to investigate the relationship between fixed residential broadband speed and housing prices. The authors apply a hedonic pricing approach and a boundary discontinuity design to construct static fixedeffect regressions that utilize broadband availability variations over time within local exchange areas as well as variations over time across local exchange boundaries. The estimations suggest a significant positive impact of broadband speed on housing prices with diminishing returns to speed. The speed elasticity of property prices amounts to 3 percent at the real mean speed of $2.2 \mathrm{Mbit} / \mathrm{s}$ and enhancing a broadband connection from low to fast speed would increase the value of a property by at most 1 percent. Based on an expansion of their baseline model, the authors subsequently discuss the benefits and costs of the DAE. For urban areas, the benefits of the speed upgrades are found to easily outweigh the costs regardless of whether FTTB technologies or the more expensive FTTH technologies are used to achieve the upgrades. In contrast, the benefits of the speed upgrades for suburban and rural areas are not sufficient to cover the costs so that a considerable share of the benefits of the coverage upgrades would be needed as well.

Ivus and Boland (forthcoming) analyze the influence of fixed broadband coverage on local employment and wage growth employing data for 4344 Canadian communities for the years from 1997 to 2011. The authors classify the communities into 76 economic regions and utilize the impact of the variation in elevation within a region on the rate of broadband deployment to use the logarithm of the former measure as the instrument in static instrumental variable regressions. While the baseline estimations do not suggest a significant effect of increases in broadband coverage, this changes when an interaction term between broadband coverage and rural areas is included. In this case, higher broadband coverage has a significant positive impact on employment growth in rural areas and a marginally significant negative impact on employment growth in urban areas. Furthermore, these effects are particularly prominent in IT-intense industries and can also be observed when only wireless broadband technologies are examined. In contrast, the baseline estimations with wage growth as the dependent variable suggest a positive influence of broadband coverage on wage growth. However, no specific impact on rural areas is found when an interaction term for rural areas is specified. Moreover, 
the authors find that the benefits of increased broadband coverage regarding employment and wage growth mainly seem to stem from the service sector whereas no effect was found for manufacturing firms.

\subsection{Productivity and firm performance}

Grimes et al. (2012) examine the impact of firms' broadband adoption on labor productivity using firm-level data for 6060 firms in New Zealand collected in 2006. As a first approach, the authors apply strata and kernel propensity score matching. It is found that broadband adoption has a significant positive effect on labor productivity within a firm implying a productivity increase of around 7 to 10 percent. However, due to high standard deviations of productivity within sectors, this increase does not translate to a strongly improved performance relative to the other firms in the sector. Furthermore, the authors observe no significant variations in productivity increases between firms in rural and urban areas as well as between firms in high and low knowledge industries. Employing dynamic instrumental variable regressions as a second approach, a significant positive effect is found that is considerably larger than the one found by propensity score matching.

Bertschek et al. (2013) employ firm-level data for Germany to analyze the relationship between firms' broadband adoption (leased line or DSL) and changes in their labor productivity and innovation activity between the years 2001 and 2003. For labor productivity (measured as sales per employee), the authors utilize a production function approach and apply the duration of DSL availability as an instrument for broadband adoption in static instrumental variable regressions. While broadband adoption initially appears to have a marginally significant positive impact on labor productivity, no such impact is found when regional differences are taken into account. Based on these findings, the authors conclude that the effects of broadband adoption vary between firms and more extensive data might be needed to observe the long-run benefits of broadband usage in its entirety. The probability of realizing a process or product innovation is estimated by a recursive binary probit model in which the duration of DSL availability is used as the exclusion restriction in the equation for broadband adoption. For both innovation types, broadband adoption is found to have a significant positive effect with average treatment effects estimated to be in the order of 41 to 45 percent for product innovations and in the order of 28 to 35 percent for process innovations. However, the authors caution that these effects might be overstated due to negative correlation between broadband adoption and unobserved factors that increase innovation activity. 
Colombo et al. (2013) examine the influence of broadband adoption on the productivity of small and medium enterprises utilizing firm- and province-level panel data for 799 Italian firms from 1998 to 2004. The authors employ principal component analyses to construct categories of broadband applications and accentuate enterprises that implemented strategic or organizational changes. Subsequently, augmented Cobb-Douglas production functions including year-fixed effects are estimated by a two-step system Generalized Method of Moments estimator. Wald test statistics suggest that the adoption of basic broadband applications such as e-banking do not significantly influence firm productivity even in combination with strategic or organizational changes. In contrast, more advanced applications are shown to be capable of significantly increasing productivity but only if they are of importance for the specific sector and are conjoined with appropriate changes in business conduct. In particular, sizeable productivity gains are experienced by firms in the manufacturing sector when 'supply chain and customer management' applications like e-mail or e-learning are adopted together with strategic changes. Similarly, firms in the service sector can raise their productivity by adopting 'advanced communications' applications like filesharing systems in combination with organizational changes. These results provide evidence that firms can only realize the potential benefits of broadband if the right set of broadband applications is combined with sufficient changes in doing business. Hence, the authors argue that public policies should actively help firms achieve these targets rather than merely provide them with monetary aid.

De Stefano et al. (2014) use plant- and firm-level panel data for the region around the city of Kingston-upon-Hull (UK) from 2000 to 2004 in order to investigate the influence of firms' ADSL broadband adoption on their performance. For this purpose, the authors initially employ static ordinary least squares regressions. The results suggest a significant positive relationship between broadband adoption and firm size, sales and sales per worker. However, no relationship between broadband adoption and sales growth or exit of firms is found. In order to obtain a causal link, a static fuzzy regression discontinuity approach is applied. This approach makes use of a spatial discontinuity in broadband availability within the city of Kingston-upon-Hull caused by two broadband providers. In this specification, the positive results of the previous estimations cease to hold and no significant impact of broadband adoption on the economic outcomes is found. Since these findings are sustained under various robustness checks, the authors conclude that ordinary least squares regressions are likely to overestimate the effects of broadband and no causal link between broadband adoption and firm performance exists for the sample under consideration. 
Akerman et al. (2015) analyze the effect of broadband availability and adoption on labor productivity with special focus on workers' skill levels using Norwegian firm-level data from 2000 to 2008. For this purpose, the authors initially conduct intention-to-treat analysis and find that increased broadband availability had a significant positive impact on the hourly wages and employment of skilled workers. Contrary to that, the hourly wages of low skilled workers were negatively affected. Similarly, broadband availability significantly increased the output elasticities of skilled workers while it significantly reduced the output elasticities of low-skilled workers. These results are in the following confirmed for broadband adoption through estimations of production functions by fixed-effect ordinary least squares and instrumental variable regressions. Moreover, broadband is adopted faster by firms that rely heavily on skilled workers. In addition to the effects mentioned above, broadband availability is also found to have a positive effect on firms' outputs. In particular, the estimations indicate that increasing broadband availability by 10 percent raises output by 0.4 percent for a fixed amount of inputs.

Haller and Lyons (2015) utilize firm-level panel data for 2290 Irish manufacturing firms from 2002 to 2009 to investigate the relationship between firms’ DSL broadband adoption and productivity as well as productivity growth. To obtain a causal link, the authors apply static fixed-effect instrumental variable regressions in which broadband adoption enters the regression equation as a dummy variable and geographical DSL broadband availability is used as an instrument for broadband adoption. Although pairwise correlations indicate that broadband adoption positively impacts firm productivity and negatively impacts productivity growth, the regressions mentioned above are unable to support these results. Instead, the authors find that neither firm productivity nor productivity growth are significantly affected by broadband adoption even though the coefficients have the expected signs. These findings continue to hold when only broadband speeds $\geq 2 \mathrm{Mbit} / \mathrm{s}$ or broadband technologies other than DSL are considered as well as when firms are classified in terms of their respective size. Furthermore, the coefficient remains insignificant when labor productivity instead of totalfactor productivity is employed as the dependent variable. Due to these results, the authors conclude that broadband adoption did not lead to higher firm productivity or productivity growth in the examined case.

Bertschek and Niebel (2016) analyze whether employees' access to mobile internet improves firms' labor productivity. The analysis is based on a firm-level data set containing 2143 firms from the German manufacturing and services industries and referring to the year 2014. At this 
time, high-speed mobile internet was still at a relatively early stage of diffusion within firms. Only 26 per cent of employees in the sample were equipped with mobile devices being able to connect to the internet. The econometric analysis shows that firms' labor productivity (measured as sales per employee) significantly increases with the share of employees with mobile internet access. ICT use at the workplace other than mobile internet is controlled for by including measures of the use of computers and access to fixe line internet. An instrumental variables approach suggests that mobile internet use does cause higher labor productivity. Positive aspects of mobile internet use such as improving information flows and supporting a more flexible organization of work with respect to time and location seem to outweigh negative aspects like higher monitoring cost.

\subsection{Conclusions on the economic impacts of broadband internet}

The main results of the reviewed papers studying the economic impacts of broadband internet are presented in ascending chronological order in Table 3 ('impact on economic growth'), Table 4 ('impacts on employment and regional development') and Table 5 ('impact on firm performance'). In each table, we apply a further separation into studies examining the impacts of broadband availability (infrastructure investment) and broadband adoption (usage).

Overall, four out of five studies that examine the impacts of broadband adoption on GDP and GDP growth with country-level data find a positive and significant effect (RQ 1). Arvin and Pradhan (2014) represents the only study with inconclusive results on the relationship between broadband and GDP. Contrary to that, the clear results in the other studies ascertain that broadband adoption indeed causes GDP growth. Given that two of the cross-country studies provide evidence for a critical mass or a stronger influence of broadband in developed countries, the impact should, however, not be assumed to be linear but rather to be increasing in the penetration rate of a country. Moreover, it seems to be necessary for countries with low broadband penetration to reach a certain penetration level if they want to experience the largest possible benefits of broadband.

The majority of studies (6 out of 7) that focus on overall employment find positive links between broadband and employment growth (RQ 1). Again, this impact is not constant: several studies that take into account differences in urbanization and workers' skill levels suggest that the effect of broadband is significant mostly in rural areas and for high-skilled workers. The stronger impact on remote areas lends support to the notion that broadband can help these regions to catch up with more economically developed urban areas. 
On the firm level, the evidence for a positive impact of broadband on productivity is mixed. While 2 studies find a significant positive effect, 2 more recent studies argue against the existence of a significant effect. Colombo et al. (2013) verify a positive impact only for advanced broadband applications in combination with strategical and organizational changes. These results provide evidence that broadband adoption does not necessarily increase firm productivity and that ICT-intensive businesses may be favored with regard to productivity growth. Furthermore, they support the theory that firms need to incorporate structural changes in business conduct in order to achieve the potential positive impact of ICT on productivity. ${ }^{2}$

In sum, we find strong evidence for positive impacts of broadband networks on economic outcomes (RQ 1). With regard to our research question referring to differences in wireline and wireless infrastructure and services (RQ 2), however, there is no conclusive evidence as only very few studies employ data related to mobile broadband networks. Concerning our third research question (RQ 3), we also find no clear evidence that broadband availability and adoption produce systematically different economic outcomes although research by Whitacre et al. (2014) indicates that certain differential impacts may exist. Moreover, it is not necessarily the fact of using broadband that matters but the type of application that is employed. Lastly, in contrast to the throughout positive impact of broadband found at the macro level, microeconomic studies do not find clear evidence for positive productivity effects of broadband on the firm level (RQ 4).

2 For related literature on ICT, see e.g. Brynjolfsson and Hitt (2000) and Cardona et al. (2013). 
Table 3: Broadband's impact on economic growth

\begin{tabular}{|c|c|c|c|}
\hline Author(s) & Data & Methodology & Main results \\
\hline \multicolumn{4}{|c|}{ Broadband adoption } \\
\hline $\begin{array}{l}\text { Koutroumpis } \\
\text { (2009) }\end{array}$ & $\begin{array}{l}22 \text { OECD } \\
\text { countries; } \\
\text { 2002-2007; } \\
\text { country-level }\end{array}$ & $\begin{array}{l}\text { Simultaneous equations model } \\
\text { estimated by instrumental } \\
\text { variable regressions and three- } \\
\text { stage least squares Generalized } \\
\text { Method of Moments with fixed } \\
\text { effects }\end{array}$ & $\begin{array}{l}\text { - Broadband adoption positively } \\
\text { impacts GDP growth } \\
\text { - Critical mass at } 30 \text { percent } \\
\text { adoption }\end{array}$ \\
\hline $\begin{array}{l}\text { Czernich } \\
\text { et al. } \\
\text { (2011) }\end{array}$ & $\begin{array}{l}25 \text { OECD } \\
\text { countries; } \\
\text { 1996-2007; } \\
\text { country-level }\end{array}$ & $\begin{array}{l}\text { Two-stage instrumental variable } \\
\text { approach: } \\
\text { 1. Two-stage least squares } \\
\text { estimation of a logistic } \\
\text { diffusion model } \\
\text { 2. Difference-in- } \\
\text { differences estimations } \\
\text { and static fixed-effect } \\
\text { cross-country growth } \\
\text { model estimation }\end{array}$ & $\begin{array}{l}\text { - Broadband introduction and } \\
\text { broadband adoption have a } \\
\text { positive effect on growth of GDP } \\
\text { per capita } \\
\text { - Critical mass at an adoption rate } \\
\text { of } 10 \text { percent }\end{array}$ \\
\hline $\begin{array}{l}\text { Thompson \& } \\
\text { Garbacz } \\
\text { (2011) }\end{array}$ & $\begin{array}{l}43 \text { countries; } \\
\text { 2005-2009; } \\
\text { country-level }\end{array}$ & $\begin{array}{l}\text { Static fixed-effect instrumental } \\
\text { variable regressions }\end{array}$ & $\begin{array}{l}\text { - Mobile broadband adoption } \\
\text { positively influences GDP per } \\
\text { household } \\
\text { - } \\
\text { Fixed broadband adoption has an } \\
\text { insignificant negative impact on } \\
\text { GDP per household }\end{array}$ \\
\hline $\begin{array}{l}\text { Arvin \& } \\
\text { Pradhan } \\
(2014)\end{array}$ & $\begin{array}{l}19 \text { of G20 } \\
\text { countries; } \\
\text { 1998-2011; } \\
\text { country-level }\end{array}$ & $\begin{array}{l}\text { Panel cointegration and Granger } \\
\text { causality tests }\end{array}$ & $\begin{array}{l}\text { - No conclusive evidence for a } \\
\text { causal relationship between } \\
\text { broadband penetration and GDP } \\
\text { growth in the long run } \\
\text { - Bidirectional causal relationship } \\
\text { between broadband penetration } \\
\text { and GDP growth for developed } \\
\text { countries in the short run }\end{array}$ \\
\hline $\begin{array}{l}\text { Gruber } \\
\text { et al. } \\
\text { (2014) }\end{array}$ & $\begin{array}{l}27 \text { EU } \\
\text { countries; } \\
\text { 2005-2011; } \\
\text { country-level }\end{array}$ & $\begin{array}{l}\text { Simultaneous equations model } \\
\text { estimated by fixed-effect three- } \\
\text { stage least squares to obtain } \\
\text { return parameters; varying } \\
\text { assumptions about economic } \\
\text { development }\end{array}$ & $\begin{array}{l}\text { - Broadband adoption has a } \\
\text { positive impact on GDP } \\
\text { - Realizing the goals of the DAE } \\
\text { would generate economic } \\
\text { benefits for the whole EU and } \\
\text { most member countries }\end{array}$ \\
\hline
\end{tabular}


Table 4: Broadband's impact on employment and regional development

\begin{tabular}{|c|c|c|c|}
\hline Author(s) & Data & Methodology & Main results \\
\hline \multicolumn{4}{|c|}{ Broadband availability } \\
\hline $\begin{array}{l}\text { Kandilov \& } \\
\text { Renkow } \\
\text { (2010) }\end{array}$ & $\begin{array}{l}\text { USA; } \\
\text { 1994-2007; ZIP } \\
\text { code- and } \\
\text { county-level }\end{array}$ & $\begin{array}{l}\text { Fixed-effect difference-in- } \\
\text { differences approach and } \\
\text { nearest neighbor propensity } \\
\text { score matching }\end{array}$ & $\begin{array}{l}\text { - Some positive effects of the pilot } \\
\text { program on employment, annual } \\
\text { payroll and number of business } \\
\text { establishments } \\
\text { - No effects of the subsequent loan } \\
\text { program }\end{array}$ \\
\hline Kolko (2012) & $\begin{array}{l}\text { USA; } \\
\text { 1992-2006; ZIP } \\
\text { code- and } \\
\text { county-level }\end{array}$ & $\begin{array}{l}\text { Static ordinary and weighted } \\
\text { two-stage least squares } \\
\text { regressions }\end{array}$ & $\begin{array}{l}\text { - A higher number of broadband } \\
\text { providers positively impacts } \\
\text { employment and population } \\
\text { growth } \\
\text { - Varying effects on employment } \\
\text { rates, average pay per employee } \\
\text { and median income }\end{array}$ \\
\hline $\begin{array}{l}\text { Atasoy } \\
(2013)\end{array}$ & $\begin{array}{l}\text { USA; } \\
\text { 1999-2007; } \\
\text { ZIP code- and } \\
\text { county-level }\end{array}$ & $\begin{array}{l}\text { Estimation of static ordinary } \\
\text { least squares and fixed-effect } \\
\text { models, Granger causality test } \\
\text { and a falsification test }\end{array}$ & $\begin{array}{l}\text { Broadband availability increases } \\
\text { employment for workers with } \\
\text { college degree but decreases } \\
\text { employment for workers without } \\
\text { college degree } \\
\text { - Employment growth mainly stems } \\
\text { from existing firms rather than } \\
\text { newly founded firms }\end{array}$ \\
\hline $\begin{array}{l}\text { Mack \& } \\
\text { Faggian } \\
(2013)\end{array}$ & $\begin{array}{l}\text { USA; } \\
\text { 1999, 2000, } \\
\text { 2007; } \\
\text { county-level } \\
\text { (partially } \\
\text { aggregated) }\end{array}$ & $\begin{array}{l}\text { Estimations of spatial lag } \\
\text { models; interaction terms } \\
\text { between broadband and } \\
\text { workers' skill } \\
\text { education/education level }\end{array}$ & $\begin{array}{l}\text { - Only workers with high } \\
\text { education/skill level benefit } \\
\text { significantly from increased } \\
\text { broadband availability } \\
\text { - Uneducated/unskilled workers are } \\
\text { negatively affected }\end{array}$ \\
\hline $\begin{array}{l}\text { Czernich } \\
\text { (2014) }\end{array}$ & $\begin{array}{l}\text { Germany; 2002- } \\
\text { 2006; } \\
\text { municipality- } \\
\text { and county-level }\end{array}$ & $\begin{array}{l}\text { Dynamic regression equations } \\
\text { estimated by ordinary least } \\
\text { squares and instrumental } \\
\text { variable regressions }\end{array}$ & $\begin{array}{l}\text { - No evidence for a significantly } \\
\text { causal impact of DSL broadband } \\
\text { availability on unemployment } \\
\text { rates }\end{array}$ \\
\hline $\begin{array}{l}\text { Mack \& } \\
\text { Rey } \\
(2014)\end{array}$ & $\begin{array}{l}\text { USA; } \\
\text { 2004, 2006; ZIP } \\
\text { code-level }\end{array}$ & $\begin{array}{l}\text { Static ordinary and two-stage } \\
\text { least squares regressions as } \\
\text { well as spatial error and spatial } \\
\text { lag models }\end{array}$ & $\begin{array}{l}\text { - Increased broadband availability } \\
\text { is associated with higher presence } \\
\text { of knowledge intensive businesses } \\
\text { in almost all observed } \\
\text { metropolitan areas }\end{array}$ \\
\hline
\end{tabular}


(Table 4: Continued)

\begin{tabular}{|c|c|c|c|}
\hline Author(s) & Data & Methodology & Main results \\
\hline \multicolumn{4}{|c|}{ Broadband availability } \\
\hline $\begin{array}{l}\text { Whitacre } \\
\text { et al. (2014) }\end{array}$ & $\begin{array}{l}\text { USA; } \\
\text { 2001-2010; } \\
\text { county-level }\end{array}$ & $\begin{array}{l}\text { Nearest neighbor propensity } \\
\text { score matching based on logit } \\
\text { propensity scores }\end{array}$ & $\begin{array}{l}\text { Broadband availability negatively } \\
\text { affects median household income } \\
\text { and non-farm proprietors income } \\
\text { in non-metropolitan areas }\end{array}$ \\
\hline $\begin{array}{l}\text { Canzian } \\
\text { et al. } \\
\text { (2015) }\end{array}$ & $\begin{array}{l}\text { Province of } \\
\text { Trento (Italy); } \\
\text { 2008-2012; } \\
\text { firm- and } \\
\text { municipality- } \\
\text { level }\end{array}$ & $\begin{array}{l}\text { Quasi-experimental set up, } \\
\text { estimations via a fixed-effect } \\
\text { difference-in-differences } \\
\text { approach }\end{array}$ & $\begin{array}{l}\text { - Introduction and expansion of } \\
\text { ADSL 2+ broadband availability } \\
\text { in rural areas positively affected } \\
\text { firms with regard to annual sales } \\
\text { turnovers and annual value added } \\
\text { - Positive impact on the number of } \\
\text { employees per firm only in rural } \\
\text { areas }\end{array}$ \\
\hline $\begin{array}{l}\text { Ahlfeldt } \\
\text { et al. } \\
\text { (forthcom- } \\
\text { ing) }\end{array}$ & $\begin{array}{l}\text { England; } \\
\text { 1995-2010; } \\
\text { individual-, } \\
\text { transaction- } \\
\text { and local } \\
\text { exchange-level }\end{array}$ & $\begin{array}{l}\text { Boundary discontinuity } \\
\text { approach estimated by static } \\
\text { fixed-effect regressions }\end{array}$ & $\begin{array}{l}\text { - Available broadband speed has a } \\
\text { significantly positive but } \\
\text { decreasing impact of property } \\
\text { prices } \\
\text { - Achieving solely the speed goals } \\
\text { of the DAE will cover the costs } \\
\text { only in urban areas }\end{array}$ \\
\hline $\begin{array}{l}\text { Ivus \& } \\
\text { Boland } \\
\text { (forthcom- } \\
\text { ing) }\end{array}$ & $\begin{array}{l}\text { Canada; } \\
\text { 1997-2011; } \\
\text { municipality- } \\
\text { level }\end{array}$ & $\begin{array}{l}\text { Grouping of municipalities into } \\
\text { economic regions; static } \\
\text { instrumental variable regressions }\end{array}$ & $\begin{array}{l}\text { - Significantly positive impact of } \\
\text { broadband availability on } \\
\text { employment growth in rural areas } \\
\text { and overall wage growth } \\
\text { - Positive impact stems from the } \\
\text { service sector }\end{array}$ \\
\hline \multicolumn{4}{|c|}{ Broadband adoption } \\
\hline $\begin{array}{l}\text { Forman et al. } \\
\text { (2012) }\end{array}$ & $\begin{array}{l}\text { USA; } \\
\text { 1995-2000; } \\
\text { county-level }\end{array}$ & $\begin{array}{l}\text { Estimations with instruments } \\
\text { and timing of regional wage } \\
\text { divergence to identify causal } \\
\text { links }\end{array}$ & 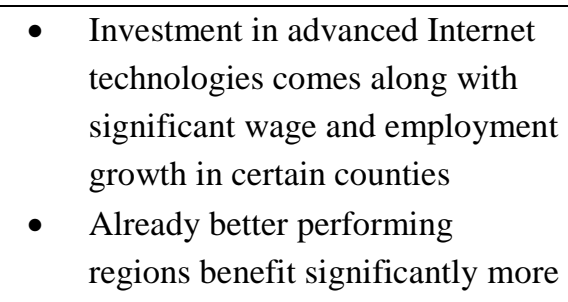 \\
\hline $\begin{array}{l}\text { Whitacre } \\
\text { et al. (2014) }\end{array}$ & $\begin{array}{l}\text { USA; } \\
\text { 2001-2010; } \\
\text { county-level }\end{array}$ & $\begin{array}{l}\text { Nearest neighbor and kernel } \\
\text { propensity score matching based } \\
\text { on logit propensity scores }\end{array}$ & $\begin{array}{l}\text { - More broadband adoption is } \\
\text { associated with faster growth of } \\
\text { employment, businesses and } \\
\text { median household income }\end{array}$ \\
\hline
\end{tabular}


Table 5: Broadband's impact on productivity and firm performance

\begin{tabular}{|c|c|c|c|}
\hline Author(s) & Data & Methodology & Main results \\
\hline \multicolumn{4}{|c|}{ Broadband availability } \\
\hline $\begin{array}{l}\text { Akerman } \\
\text { et al. } \\
\text { (2015) }\end{array}$ & $\begin{array}{l}\text { Norway; } \\
\text { 2000-2008; } \\
\text { firm-level }\end{array}$ & $\begin{array}{l}\text { Intention-to-treat analysis, } \\
\text { estimations of production } \\
\text { functions by ordinary least } \\
\text { squares and fixed-effect } \\
\text { instrumental variable regressions }\end{array}$ & $\begin{array}{l}\text { Broadband availability (and } \\
\text { adoption) positively affects the } \\
\text { employment and wages of skilled } \\
\text { workers but negatively affects } \\
\text { wages of low-skilled workers } \\
\text { - Further positive impact on firms' } \\
\text { output }\end{array}$ \\
\hline \multicolumn{4}{|c|}{ Broadband adoption } \\
\hline $\begin{array}{l}\text { Grimes } \\
\text { et al. } \\
(2012)\end{array}$ & $\begin{array}{l}\text { New Zealand; } \\
\text { 2006; } \\
\text { firm-level }\end{array}$ & $\begin{array}{l}\text { Strata and kernel propensity } \\
\text { score matching with probit } \\
\text { propensity scores, instrumental } \\
\text { variable regressions as } \\
\text { robustness checks }\end{array}$ & $\begin{array}{l}\text { - More broadband adoption is } \\
\text { associated with increased labor } \\
\text { productivity } \\
\text { - No differences between } \\
\text { urban/rural areas and high/low } \\
\text { technology industries }\end{array}$ \\
\hline $\begin{array}{l}\text { Bertschek } \\
\text { et al. } \\
\text { (2013) }\end{array}$ & $\begin{array}{l}\text { Germany; } \\
\text { 2001-2003; } \\
\text { firm-level }\end{array}$ & $\begin{array}{l}\text { Production function approach } \\
\text { estimated by static instrumental } \\
\text { variable regressions to estimate } \\
\text { changes in labor productivity; } \\
\text { recursive binary probit approach } \\
\text { to estimate the probability of } \\
\text { innovations }\end{array}$ & $\begin{array}{l}\text { - Broadband usage has a significant } \\
\text { positive impact on firms' } \\
\text { innovation activities } \\
\text { - No effect on labor productivity }\end{array}$ \\
\hline $\begin{array}{l}\text { Colombo } \\
\text { et al. } \\
\text { (2013) }\end{array}$ & $\begin{array}{l}\text { Italy; } \\
\text { 1998-2004; } \\
\text { firm-level }\end{array}$ & $\begin{array}{l}\text { Augmented Cobb-Douglas } \\
\text { production functions estimated } \\
\text { by two-step system Generalized } \\
\text { Method of Moments including } \\
\text { year-fixed effects }\end{array}$ & $\begin{array}{l}\text { - Adoption of basic broadband } \\
\text { application does not increase } \\
\text { firms' productivity } \\
\text { - More advanced broadband } \\
\text { applications can be beneficial if } \\
\text { they are combined with strategic } \\
\text { or organizational changes }\end{array}$ \\
\hline $\begin{array}{l}\text { De Stefano et } \\
\text { al. } \\
\text { (2014) }\end{array}$ & $\begin{array}{l}\text { Kingston-upon- } \\
\text { Hull (UK); } \\
\text { 2000- } \\
\text { 2004;plant- and } \\
\text { firm-level }\end{array}$ & $\begin{array}{l}\text { Ordinary least squares } \\
\text { regressions and a fuzzy } \\
\text { discontinuity regression } \\
\text { approach are used to estimate } \\
\text { the static regression equations }\end{array}$ & $\begin{array}{l}\text { - Increased ADSL adoption does } \\
\text { not lead to significant changes in } \\
\text { firm performance }\end{array}$ \\
\hline $\begin{array}{l}\text { Haller \& } \\
\text { Lyons (2015) }\end{array}$ & $\begin{array}{l}\text { Ireland; } \\
\text { 2002-2009; } \\
\text { firm-level }\end{array}$ & $\begin{array}{l}\text { Static regression equations } \\
\text { estimated by fixed-effect } \\
\text { instrumental variable regressions }\end{array}$ & $\begin{array}{l}\text { - No effect of DSL broadband } \\
\text { adoption on firm productivity and } \\
\text { productivity growth }\end{array}$ \\
\hline
\end{tabular}


(Table 5: Continued)

\begin{tabular}{|c|c|c|c|}
\hline Authors & Data & Methodology & Main results \\
\hline \multicolumn{4}{|c|}{ Broadband adoption } \\
\hline $\begin{array}{l}\text { Bertschek \& } \\
\text { Niebel (2016) }\end{array}$ & $\begin{array}{l}\text { Germany; } \\
\text { 2014; } \\
\text { firm-level }\end{array}$ & $\begin{array}{l}\text { Production function approach } \\
\text { estimated by static instrumental } \\
\text { variable regressions to estimate } \\
\text { changes in labor productivity }\end{array}$ & $\begin{array}{l}\text { Firms' labor productivity } \\
\text { significantly increases with the } \\
\text { share of employees with mobile } \\
\text { internet access }\end{array}$ \\
\hline
\end{tabular}




\section{Conclusions and policy recommendations}

In this article, we have provided a survey of quantitative research on the economic impacts of telecommunications networks and broadband internet. Differentiating between wireline and wireless technologies as well as broadband availability and broadband adoption, respectively, we have reviewed studies investigating the causal effects on productivity and various measures of firm performance, economic growth, employment and regional development.

Aiming at relating the main insights of our survey to the four research questions identified in the introduction, we first find that both telecommunications and broadband infrastructure and services tend to exert a positive impact on economic growth as well as on productivity (RQ 1). On a macroeconomic level (RQ 4), increased broadband deployment not only translates into higher economic growth and productivity but also helps to create new jobs and, at least partially, facilitates economic development in rural areas. However, the impact on regional development is mixed as several studies also find insignificant effects. Overall, focusing on these findings only suggests that promoting broadband deployment is an effective measure to realize welfare gains (RQ 1). The microeconomic studies under review (RQ 4), however, paint a more differentiated picture. Most notably, broadband adoption is accompanied by a pronounced skill bias regarding workers' labor market outcomes that strongly favors highly skilled workers. While skilled workers enjoy higher wages and employment rates as well as a rise in productivity as a consequence of broadband adoption, workers with lower skill levels experience higher unemployment and lower wages. Accordingly, business establishments that are ICT intensive and require a relatively large amount of skilled workers such as the service sector are observed to be the main beneficiaries of broadband. In contrast, industries such as the manufacturing sector that rely heavily on manual labor are not or even negatively affected. Furthermore, firms may need to implement changes in doing business in order to materialize the possible economic advantages of broadband usage.

Regarding the differential impact of fixed and mobile broadband technologies (RQ 2), there is hardly any empirical evidence available. Wireline and mobile telecommunications differ, however, with regard to the country-specific distribution of their benefits. Wireline telecommunications are found to have the strongest effect in developed countries exhibiting almost nation-wide coverage. Furthermore, the reviewed studies provide evidence that mobile telecommunications are particularly advantageous for economic growth and productivity in 
developing countries with much less developed wireline infrastructure. Since developing countries can often still achieve sizeable increases in telecommunications usage and consequently economic growth, our main policy implication in this regard is therefore that developing countries should mostly focus on designing and implementing policies that facilitate the deployment of mobile telecommunications or directly deploy wireline next generations broadband networks especially if those countries currently possess a low level of old wireline telecommunications infrastructure.

The estimated coefficients in the investment or infrastructure-related empirical specifications represent the impact of broadband availability on economic outcomes but not the effect related to actual usage of broadband and telecommunications services (RQ 3). Whereas the former measures the intention-to-treat effect, the latter directly impacts on economic outcomes measuring the average treatment effect. Apparently, adoption of services is a function of availability of the underlying infrastructure. Accordingly, the empirical studies employing measures of availability only estimate a reduced-form model where the estimated coefficients represent a proportional effect which is smaller than the effect via broadband usage (Czernich, 2014). In that sense, impact assessments of the infrastructure availability actually tend to underestimate economic impacts and realized welfare gains. At the same time these studies are more informative from a policy perspective which is mainly targeted at the supply-side, i.e. investment by broadband providers, via regulation or public funding. In fact, according to our review of the literature, almost all adoption-related broadband studies find positive effects on economic outcomes whereas this finding is clearly less evident in availability-related broadband studies (RQ 3).

Our findings have further specific implications for policy makers. The existence of network effects and the often small incentives for broadband providers to supply rural areas due to high costs and low revenues suggest that public initiatives and financial aid should be considered as instruments to achieve increased broadband development, particularly in countries with a large share of the population living outside of urban areas. At the same time, however, policy makers will have to take into account the distributional effects that are caused by the skill bias of broadband adoption. Accordingly, it appears necessary to accompany broadband policies with increased investments in education for both individuals (general education and advanced training on the job) and firms (to facilitate changes in business conduct). Such policies would increase not only the share of workers benefitting from 
broadband by enabling them to find employment in ICT-intensive jobs but also the overall impacts of broadband on economic growth and employment.

Turning from the main insights and policy implications of our survey to the identification of main research gaps, despite the great variety of data sets and methodologies applied in the reviewed studies, several limitations still remain. Firstly, a large number of studies focusing on the impact of broadband on regional development employ measures of the mere existence of broadband infrastructure instead of actual broadband adoption as explanatory variables. Albeit previous literature (e.g. Cava-Ferreruela and Alabau-Munoz, 2006; Akerman et al., 2015) generally indicates that the relationship between broadband availability and broadband adoption is positive, broadband availability only serves as a pre-condition for broadband adoption. In this regard Whitacre et al. (2014) suggest that the influence of broadband availability and actual broadband adoption can differ considerably. Moreover, the FCC data which is used in most U.S. studies often measures broadband availability as the number of broadband providers in a ZIP code. This measure has been repeatedly criticized in the related literature (e.g. Grubesic, 2008; Holt and Jamison, 2009) for not accurately measuring broadband availability.

Another gap in the existing research on the economic impacts of broadband is that only very few studies specifically investigate the impact of broadband speed on economic outcomes. In fact, most studies define broadband very broadly as internet connections with download speeds greater than $200 \mathrm{Kbit} / \mathrm{s}$ and do not account for faster broadband speeds or different broadband technologies. However, it seems likely that different speeds will have different effects and that some industries might benefit in particular from higher broadband speeds. Future research should hence focus on the impact of broadband speed, in particular, with respect to the current deployment of next-generation broadband networks which will gradually replace old broadband networks and provide broadband speeds as targeted in the Digital Agenda for Europe (DAE) in the EU or the National Broadband Plan in the U.S. Meanwhile these targets have been implemented in most EU member states in national broadband plans which are in many cases targeted at even more ambitious coverage and adoption levels ${ }^{3}$.

Accordingly, assessing the costs and benefits appears to be of high policy relevance. In order to estimate costs and benefits of reaching the DAE goals, Gruber et al. (2014) examine several

3 See https://ec.europa.eu/digital-single-market/en/broadband-member-states (last accessed on 29 July 2016) for further information. 
scenarios to account for different economic developments. The authors further find that returns exceed costs for the whole European Union in all cases with base case estimates projecting net cumulative gains to be in the magnitude of $€ 282$ billion. Given that costs are estimated to be $€ 213.6$ billion, this implies that the net gains will exceed costs by 32 percent in the base case. On an individual level, most countries should benefit from achieving the goals of the DAE although the extent of these benefits varies considerably among the member states depending on their already existing broadband infrastructure stock and rate of urbanization. The authors conclude that public subsidies might be necessary to realize the complete benefits of broadband as private firms would not fully supply the infrastructure otherwise. Ahlfeldt et al. (forthcoming) also found that the speed upgrades easily outweigh the costs regardless of which fiber technologies are actually used. However, this holds only for urban areas, whereas the benefits of the speed upgrades for suburban and rural areas are not sufficient to cover the costs.

Although Gruber et al. (2014) explicitly include high-speed next generation broadband technologies, reliable and broad evidence on economic impacts of high-speed wireline or wireless broadband infrastructure and adoption is still largely missing so far but of great policy relevance, in particular for the public funding of such networks.

While a multitude of studies examine the effects of wireline and wireless telecommunications on macroeconomic growth and productivity with country-level data, the number of studies that investigate the impacts of telecommunications and broadband infrastructure on firm or household level is much smaller. For that reason, the existing literature so far only allows valid conclusions on the aggregated effects of telecommunications and broadband networks but not on the distribution of benefits within the observation units. A more granular analysis is also necessary to gain insights on whether infrastructure availability and services help rural areas to catch up with urban areas, i.e. whether closing the digital divide also closes the economic divide. Moreover, further research is needed with respect to the labor market effects of telecommunications and broadband networks, in particular on employment and wage growth, in order to further examine whether the deployment of networks is accompanied by complementarities related to education or the adoption of other ICT services. 


\section{Appendix: Relevant telecommunications networks and technologies}

With regard to the distinction between wireline and wireless networks, we follow the International Telecommunication Union (ITU) which defines fixed telephone lines as 'active line[s] connecting the subscriber's terminal equipment to the public switched telephone networks [PSTN] and which has a dedicated port in the telephone exchange equipment' (ITU 2010, pp. 1) and accordingly includes 'analog fixed telephone lines, Integrated Services Digital Network (ISDN) channels, fixed wireless, public payphones and VoIP [Voice over Internet Protocol] subscriptions' (ITU 2010, pp. 1). Given that active lines had to be utilized within three months prior to the ITU data collection, studies that employ the number of mainlines will be defined as examining telecommunications adoption (actual usage) and not merely telecommunications availability (the existence of infrastructure).

Mobile phone subscriptions refer to 'the subscriptions to a public mobile telephone service and provides access to Public Switched Telephone Network using cellular technology, including number of pre-paid Subscriber Identity Module (SIM) cards actively during the past three months. This includes both analogue and digital cellular systems (IMT-2000 Third Generation, 3G and 4G subscriptions), but excludes mobile broadband subscriptions via data cards or USB [Universal Serial Bus] modems’ (ITU 2010, pp. 3).

Our definition of fixed broadband will include both fixed wired technologies (such as cable modem, xDSL and FTTH/B/C/N technologies) as well as fixed wireless hybrid technologies such as Wi-Fi (WLAN). It should be noted at this point that most of the reviewed studies employ very broad definitions of fixed broadband with regard to broadband speed. While the lowest speed threshold in a study is set at $128 \mathrm{Kbit} / \mathrm{s}$, a majority of the research that analyzes the effects of broadband availability in the US employs data from the FCC which, until 2010, defined broadband as an internet connection with either up- or downstream speeds of at least $200 \mathrm{Kbit} / \mathrm{s}$ (see FCC 2010b). Similarly, most cross-country studies as well as several other publications make use of OECD (2016) and ITU (2010) standards which associate broadband with download speeds of at least $256 \mathrm{Kbit} / \mathrm{s}$. Studies utilizing German data, on the other hand, apply slightly higher thresholds at 384 or $768 \mathrm{Kbit} / \mathrm{s}$.

Finally, mobile broadband will, in line with ITU (2010), be comprised of both satellite and terrestrial mobile wireless subscriptions that achieve download speeds of $256 \mathrm{Kbit} / \mathrm{s}$ or more. Accordingly, mobile broadband includes, in particular, Universal Mobile 
Telecommunications System (UMTS) 3G, 4G, Worldwide Interoperability for Microwave Access (WiMAX) and Long Term Evolution (LTE) technologies.

As a consequence, fixed and mobile technologies below the above-mentioned bandwidth thresholds are defined as narrowband telecommunications infrastructures and services which we simply refer to as telecommunications networks in the following. 


\section{References}

Ahlfeldt, G., Koutroumpis, P., \& Valletti, T. (forthcoming). Speed 2.0-Evaluating Access to Universal Digital Highways. Journal of the European Economic Association.

Aker, J. C. (2010). Information from Markets Near and Far: Mobile Phones and Agricultural Markets in Niger. American Economic Journal: Applied Economics, 2(3), pp. 46-59.

Akerman, A., Gaarder, I., \& Mogstad, M. (2015). The Skill Complementarity of Broadband Internet. Quarterly Journal of Economics, 130(4), pp. 1781-1824.

Arvin, B. M., \& Pradhan, R. P. (2014). Broadband Penetration and Economic Growth Nexus: Evidence from Cross-country Panel Data. Applied Economics, 46(35), pp. 4360-4369.

Atasoy, H. (2013). The Effects of Broadband Internet Expansion on Labor Market Outcomes. Industrial \& Labor Relations Review, 66(2), pp. 315-345.

Barro, R. J. (1991). Economic Growth in a Cross Section of Countries. Quarterly Journal of Economics, 106(2), pp. 407-443.

Bertschek, I., \& Niebel, T. (forthcoming). Mobile and More Productive? Firm-Level Evidence on the Productivity Effects of Mobile Internet Use. Telecommunications Policy.

Bertschek, I., Cerquera, D., \& Klein, G. J. (2013). More Bits-More Bucks? Measuring the Impact of Broadband Internet on Firm Performance. Information Economics and Policy, 25(3), pp. 190-203.

Brynjolfsson, E., \& Hitt, L. M. (2000). Beyond Computation: Information Technology, Organizational Transformation and Business Performance. The Journal of Economic Perspectives, 14(4), pp. 23-48.

Canzian, G., Poy, S., \& Schüller, S. (2015). Broadband Diffusion and Firm Performance in Rural Areas: Quasi-Experimental Evidence, IZA Discussion Papers no. 9429. Retrieved from: http://www.econstor.eu/bitstream/10419/124938/1/dp9429.pdf (Last accessed on 29 July 2016).

Cardona, M., Kretschmer, T., \& Strobel, T. (2013). ICT and Productivity: Conclusions from the Empirical Literature. Information Economics and Policy, 25(3), pp. 109-125.

Cava-Ferreruela, I., \& Alabau-Munoz, A. (2006). Broadband Policy Assessment: A Crossnational Empirical Analysis. Telecommunications Policy, 30(8), pp. 445-463. 
Chakraborty, C., \& Nandi, B. (2011). 'Mainline’ Telecommunications Infrastructure, Levels of Development and Economic Growth: Evidence from a Panel of Developing Countries. Telecommunications Policy, 35(5), pp. 441-449.

Cieślik, A., \& Kaniewsk, M. (2004). Telecommunications Infrastructure and Regional Economic Development: The Case of Poland. Regional Studies, 38(6), pp. 713-725.

Colombo, M. G., Croce, A., \& Grilli, L. (2013). ICT Services and Small Businesses' Productivity Gains: An Analysis of the Adoption of Broadband Internet Technology. Information Economics and Policy, 25(3), pp. 171-189.

Crandall, R. W., \& Jackson, C. L. (2001). The \$500 Billion Opportunity: The Potential Economic Benefit of Widespread Diffusion of Broadband Internet Access. Washington, DC: Criterion Economics, LLC. Retrieved from: http://www.ntia.doc.gov/legacy/ntiahome/broadband/comments/verizon/ExhibitA.pdf (Last accessed on 29 July 2016).

Cronin, F. J., Colleran, E. K., Herbert, P. L., \& Lewitzky, S. (1993). Telecommunications and Growth: The Contribution of Telecommunications Infrastructure Investment to Aggregate and Sectoral Productivity. Telecommunications Policy, 17(9), pp. 677-690.

Cronin, F. J., Parker, E. B., Colleran, E. K., \& Gold, M. A. (1991). Telecommunications Infrastructure and Economic Growth: An Analysis of Causality. Telecommunications Policy, 15(6), pp. 529-535.

Czernich, N. (2014). Does Broadband Internet Reduce the Unemployment Rate? Evidence for Germany. Information Economics and Policy, 29, pp. 32-45.

Czernich, N., Falck, O., Kretschmer, T., \& Woessmann, L. (2011). Broadband Infrastructure and Economic Growth. The Economic Journal, 121(552), pp. 505-532.

Datta, A., \& Agarwal, S. (2004). Telecommunications and Economic Growth: A Panel Data Approach. Applied Economics, 36(15), pp. 1649-1654.

De Stefano, T., Kneller, R., \& Timmis, J. (2014). The (Fuzzy) Digital Divide: The Effect of Broadband Internet Use on UK Firm Performance. University of Nottingham Discussion Papers in Economics, (14/06). Retrieved from: http://beta.nottingham.ac.uk/economics/documents/discussion-papers/14-06.pdf $\quad$ (Last accessed on 29 July 2016). 
Draca, M., Sadun, R., \& Van Reenen, J. (2007). Productivity and ICT: A Review of the Evidence. In R. Mansell (Ed.), The Oxford Handbook of Information and Communication Technologies (pp. 100-147). Oxford University Press.

Dutta, A. (2001). Telecommunications and Economic Activity: An Analysis of Granger Causality. Journal of Management Information Systems, 17(4), pp. 71-95.

European Commission (2010). A Digital Agenda for Europe. Retrieved from: http://eurlex.europa.eu/legal-content/EN/TXT/PDF/?uri=CELEX:52010DC0245\&from=EN （Last accessed on 29 July 2016).

FCC (2010a). Connecting America: The National Broadband Plan. Retrieved from: https://transition.fcc.gov/national-broadband-plan/national-broadbandplan.pdf (Last accessed on 29 July 2016).

FCC (2010b). Sixth Broadband Deployment Report. Retrieved from: https://apps.fcc.gov/edocs_public/attachmatch/FCC-10-129A1_Rcd.pdf (Last accessed on 29 July 2016).

Forero, M. D. P. B. (2013). Mobile Communication Networks and Internet Technologies as Drivers of Technical Efficiency Improvement. Information Economics and Policy, 25(3), pp. 126-141.

Forman, C., A. Goldfarb \& Greenstein, S. (2012). The Internet and Local Wages: A Puzzle. American Economic Review, 102, 556-575.

Greenstein, S. M., \& Spiller, P. T. (1995). Modern Telecommunications Infrastructure and Economic Activity: An Empirical Investigation. Industrial and Corporate Change, 4(4), pp. 647-665.

Grimes, A., Ren, C., \& Stevens, P. (2012). The Need for Speed: Impacts of Internet Connectivity on Firm Productivity. Journal of Productivity Analysis, 37(2), pp. 187-201.

Gruber, H., Hätönen, J., \& Koutroumpis, P. (2014). Broadband Access in the EU: An Assessment of Future Economic Benefits. Telecommunications Policy, 38(11), pp. 10461058.

Gruber, H., \& Koutroumpis, P. (2011). Mobile Telecommunications and the Impact on Economic Development. Economic Policy, 26(67), pp. 387-426.

Grubesic, T. H. (2008). Spatial Data Constraints: Implications for Measuring Broadband. Telecommunications Policy, 32(7), pp. 490-502. 
Haller, S. A., \& Lyons, S. (2015). Broadband Adoption and Firm Productivity: Evidence from Irish Manufacturing Firms. Telecommunications Policy, 39(1), pp. 1-13.

Holt, L., \& Jamison, M. (2009). Broadband and Contributions to Economic Growth: Lessons from the US Experience. Telecommunications Policy, 33(10), pp. 575-581.

ITU (2010). Definitions of World Telecommunication/ICT Indicators. March 2010, ITU, Geneva. $\quad$ Retrieved from: https://www.itu.int/ITUD/ict/material/TelecomICT_Indicators_Definition_March2010_for_web.pdf $\quad$ (Last accessed on 29 July 2016).).

Ivus, O., \& Boland, M. (forthcoming). The Employment and Wage Impact of Broadband Deployment in Canada. Canadian Journal of Economics. Retrieved from: https://www.researchgate.net/publication/266739303_The_Employment_and_Wage_Impa ct_of_Broadband_Deployment_in_Canada (Last accessed on 29 July 2016).

Jensen, R. (2007). The Digital Provide: Information (Technology), Market Performance, and Welfare in the South Indian Fisheries Sector. Quarterly Journal of Economics, 122(3), pp. 879-924.

Kandilov, I. T., \& Renkow, M. (2010). Infrastructure Investment and Rural Economic Development: An Evaluation of USDA's Broadband Loan Program. Growth and Change, 41(2), pp. 165-191.

Kolko, J. (2012). Broadband and Local Growth. Journal of Urban Economics, 71(1), pp. 100113.

Koutroumpis, P. (2009). The Economic Impact of Broadband on Growth: A Simultaneous Approach. Telecommunications Policy, 33(9), pp. 471-485.

Lam, P. L., \& Shiu, A. (2010). Economic Growth, Telecommunications Development and Productivity Growth of the Telecommunications Sector: Evidence Around the World. Telecommunications Policy, 34(4), pp. 185-199.

Lee, S. H., Levendis, J., \& Gutierrez, L. (2012). Telecommunications and Economic Growth: An Empirical Analysis of Sub-Saharan Africa. Applied Economics, 44(4), pp. 461-469.

Mack, E., \& Faggian, A. (2013). Productivity and Broadband The Human Factor. International Regional Science Review, 36(3), pp. 392-423. 
Mack, E. A., \& Rey, S. J. (2014). An Econometric Approach for Evaluating the Linkages between Broadband and Knowledge Intensive Firms. Telecommunications Policy, 38(1), pp. 105-118.

Madden, G., \& Savage, S. J. (1998). CEE Telecommunications Investment and Economic Growth. Information Economics and Policy, 10(2), pp. 173-195.

Madden, G., \& Savage, S. J. (2000). Telecommunications and Economic Growth. International Journal of Social Economics, 27(7/8/9/10), pp. 893-906.

Mankiw, N. G., Romer, D., \& Weil, D. N. (1992). A Contribution to the Empirics of Economic Growth. Quarterly Journal of Economics, 107(2), pp. 407-437.

Muto, M., \& Yamano, T. (2009). The Impact of Mobile Phone Coverage Expansion on Market Participation: Panel Data Evidence from Uganda. World Development, 37(12), pp. 1887-1896.

OECD (2016), Households with Broadband Access (Indicator). Retrieved from: https://data.oecd.org/broadband/households-with-broadband-access.htm (Last accessed on 29 July 2016).

Röller, L. H., \& Waverman, L. (2001). Telecommunications Infrastructure and Economic Development: A Simultaneous Approach. American Economic Review, 91(4), pp. 909-923.

Shiu, A., \& Lam, P. L. (2008). Causal Relationship between Telecommunications and Economic Growth in China and its Regions. Regional Studies, 42(5), pp. 705-718.

Sridhar, K. S., \& Sridhar, V. (2007). Telecommunications Infrastructure and Economic Growth: Evidence from Developing Countries. Applied Econometrics and International Development, 7(2), pp. 37-56.

Thompson, H. G., \& Garbacz, C. (2007). Mobile, fixed-line and Internet service effects on global productive efficiency. Information Economics and Policy, 19(2), pp. 189-214.

Thompson, H. G., \& Garbacz, C. (2011). Economic Impacts of Mobile Versus Fixed Broadband. Telecommunications Policy, 35(11), pp. 999-1009.

Ward, M. R., \& Zheng, S. (2016). Mobile Telecommunications Service and Economic Growth: Evidence from China. Telecommunications Policy, 40(2-3), pp. 89-101.

Waverman, L., Meschi, M., \& Fuss, M. (2005). The Impact of Telecoms on Economic Growth in Developing Countries. Vodafone Policy Paper Series, 2, pp. 10-23. Retrieved from: https://www.vodafone.com/content/dam/vodafone/about/public_policy/ 
policy_papers/public_policy_series_2.pdf (Last accessed on 29 July 2016).

Whitacre, B., Gallardo, R., \& Strover, S. (2014). Broadband's Contribution to Economic Growth in Rural Areas: Moving Towards a Causal Relationship. Telecommunications Policy, 38(11), pp. 1011-1023.

Yilmaz, S., Haynes, K. E., \& Dinc, M. (2002). Geographic and Network Neighbors: Spillover Effects of Telecommunications Infrastructure. Journal of Regional Science, 42(2), pp. 339360. 